
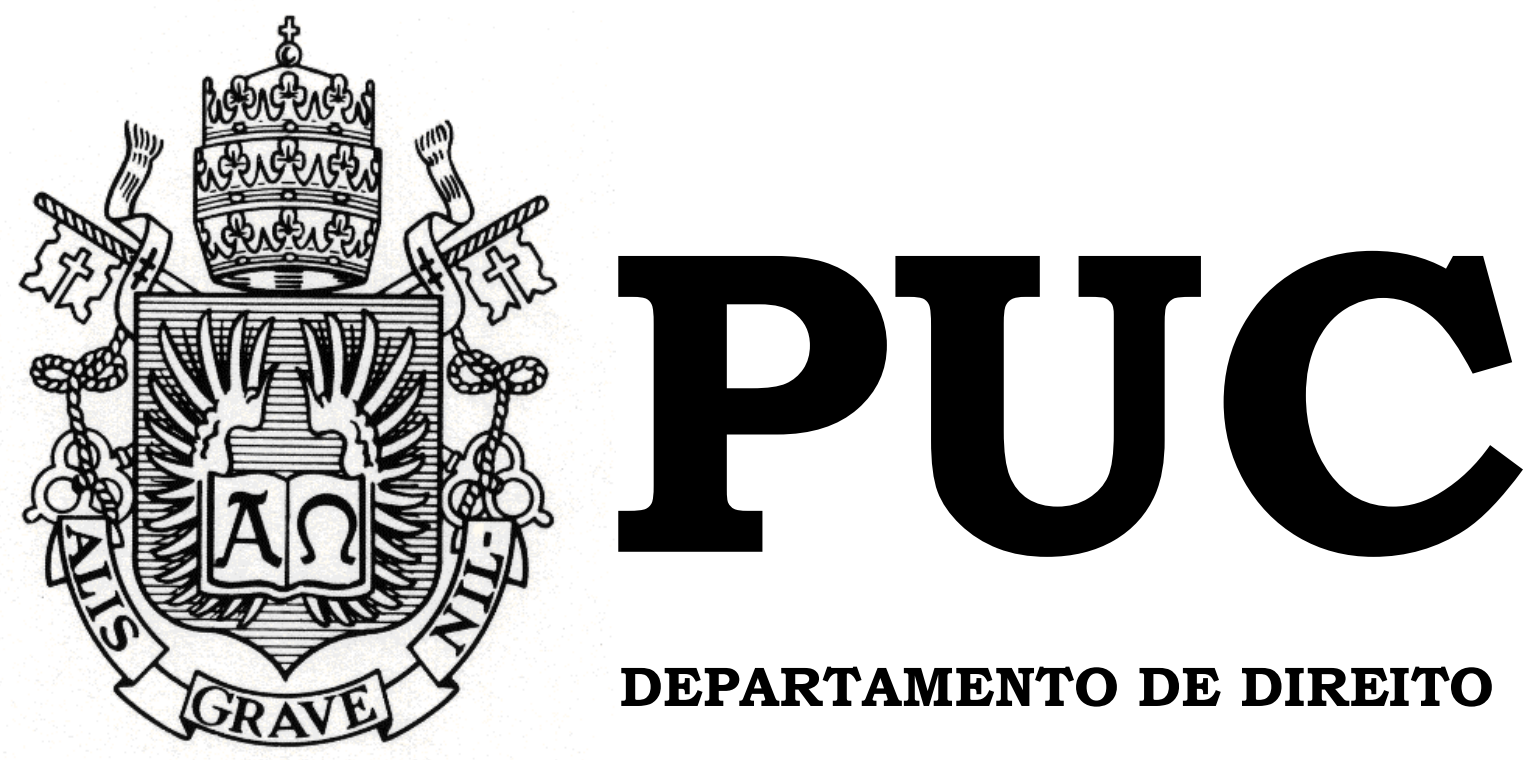

DEPARTAMENTO DE DIREITO

\title{
BRANQUITUDE E RELIGIÃO: A LUTA POR RESPEITO DAS RELIGIÕES DE MATRIZES AFRICANAS NO BRASIL
}

Por

\section{LUÍZA RIBEIRO BORGES}

ORIENTADORA: THULA RAFAELA DE OLIVEIRA PIRES

2017.2

PONTIFÍCIA UNIVERSIDADE CATÓLICA DO RIO DE JANEIRO

RUA MARQUÊS DE SÃO VICENTE, 225 - CEP 22451-900

RIO DE JANEIRO - BRASIL 


\title{
BRANQUITUDE E RELIGIÃO: A LUTA POR RESPEITO DAS RELIGIÕES DE MATRIZES AFRICANAS NO BRASIL
}

\author{
por \\ LUİZA RIBEIRO BORGES

\begin{abstract}
Monografia apresentada ao
Departamento de Direito da

Pontifícia Universidade Católica do

Rio de Janeiro (PUC-Rio) para a

obtenção do Título de Bacharel em

Direito.
\end{abstract}

Orientadora: Thula Rafaela de Oliveira Pires

2017.2 
Dedico,

A todos os adeptos de religiões

de matrizes africanas que já sofreram, sofrem ou irão sofrer qualquer tipo de preconceito por causa de sua religião. Nossa voz não irá se calar! E, em memória do meu avô, Carlos Vago Ribeiro, a quem devo muito do que eu sou. 


\section{AGRADECIMENTOS}

Agradeço, primeiramente, às amigas e aos amigos que fizeram parte dessa caminhada porque sem eles esses 5 anos de jornada não teriam sidos os mesmos.

À PUC-Rio por me proporcionar a oportunidade de poder completar meus estudos ao me incluir no quadro de bolsista da instituição.

Aos meus pais por todas as batalhas que vocês travaram para me fazer chegar até aqui! E ao meu irmão por ser o melhor amigo que poderia ter.

Ao CNPq pela oportunidade de ter sido bolsista no PIBIC realizado na PUC - Rio que me trouxe imensos aprendizados.

A todos os mestres e mestras que passaram pela minha caminhada nesta faculdade, graças a todos pude aprender sempre um pouco mais e abrir a mente para diferentes tipos de discursos.

Agradeço, em especial, e imensamente, à minha parceira e orientadora de monografia, Thula Rafaela de Oliveira Pires, pois sem você esse projeto nunca seria possível. Minha admiração e carinho só crescem! Essa monografia também é sua!

Ao meu namorado, Caio, por ser sempre tão companheiro, amigo e me acompanhar em cada projeto como se fosse seu! 
Resumo: Esta monografia consistirá, inicialmente, em estabelecer a relação entre o racismo, dentre as suas inúmeras formas, intolerância religiosa e a negação de direitos a pretos e pardos na sociedade brasileira. A partir da concepção de que o racismo e a branquitude são construções históricosociais, será feito o exame de suas consequências no comportamento da sociedade, tanto na forma de instituição como de interação entre indivíduos, principalmente acerca dos direitos à liberdade de culto e crença no Brasil, relacionando com a perversa realidade de discriminação das religiões de matrizes africanas. Dessa forma, será observada a ligação entre as cargas históricas de concepção de comportamento dentro da sociedade e sua ligação com os constantes casos de perseguição religiosa contra as religiões de matrizes africanas que sempre foram marginalizadas.

Palavras-chave: Religião. Estado. Negro. Branco. Branquitude. Identidade. Separação. Religião de matriz africana. Afro. 


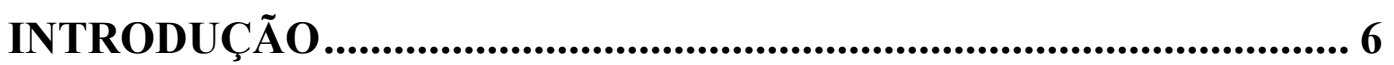

CAPÍTULO I - A HERANÇA DA ESCRAVIDÃO .................................. 9

1.1 "Sinhô branco também furta, quando faz a escravidão" ................... 9

1.2 O medo do branco ao silêncio do negro ........................................ 13

1.3 Sincretizados na fé: entre o santo e batuque................................... 16

CAPÍTULO II - BRANQUITUDE ........................................................ 21

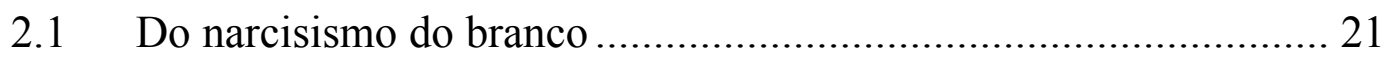

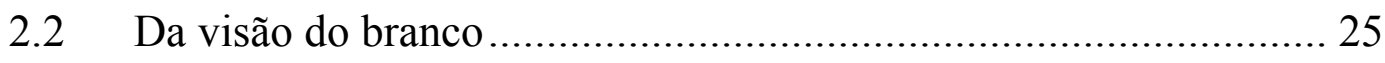

2.3 O racismo institucional: dos privilégios ......................................... 29

CAPÍTULO III - "NAS LUTAS, NAS BATALHAS. SIM, VOU NO TERREIRO PRA BATER O MEU TAMBOR" - AS RELIGIÕES DE MATRIZES AFRICANAS NO BRASIL ............................................ 32

3.1 O surgimento dos terreiros: a legalização das casas ....................... 32

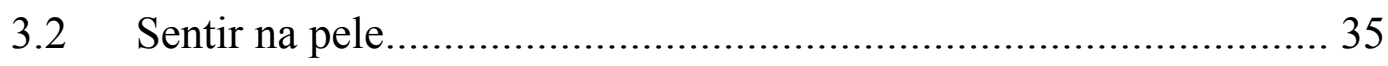

3.3 “Chuta que é macumba!": a repressão disfarçada pelas denúncias . 40 CAPÍTULO IV - ENTRE ESTADO E RELIGIÃO.............................. 43

4.1 O poder simbólico das leis............................................................. 43

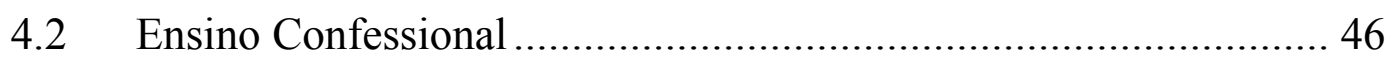

4.3 Abate de animais em rituais religiosos......................................... 50

4.4 A federalização dos crimes de intolerância religiosa........................ 55

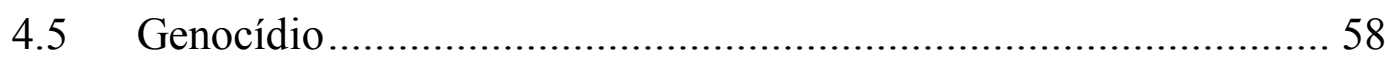

CONCLUSÃO - Cadê o respeito? ............................................................ 61

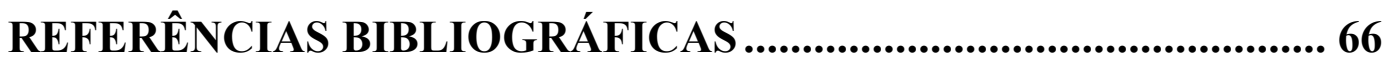




\section{INTRODUÇÃO}

A presente monografia tem por objetivo examinar os contornos acerca das heranças históricas da nossa sociedade, especificamente no que tange ao racismo e branquitude relacionando-os com o espaço que as religiões de matrizes africanas têm em nossa sociedade.

Para tanto, será necessária a análise do conceito de branquitude como forma de construção social de comportamento e suas consequências acerca da nossa realidade racial.

O tema foi escolhido devido a sua necessidade de ser tratado, conforme se verá a seguir, o debate acerca desse tema é muito restrito estando sujeito às inúmeras limitações impostas por uma hegemonia branca.

Conforme será demonstrado ao longo do trabalho, o papel do negro em nossa sociedade sempre foi menosprezado e marginalizado. Com a escravidão, o negro passou a ser apenas uma forma de mão-de-obra necessária numa sociedade que estabeleceu a brancura como parâmetro normativo de superioridade e respeito. Através das inúmeras restrições às reuniões, cultos e aos batuques durante o Brasil colonial e imperial, restou ao povo negro se adaptar à realidade imposta de uma maneira superficial, acarretando uma falsa ideia de sincretismo religioso entre as religiões de matriz africana e a católica, tão mítica quanto a ideia de democracia racial.

Essa realidade de hegemonia branca e de superioridade de raça se estende até hoje. A branquitude e a masculinidade hegemônica nos postos de poder fazem com que seja reproduzido um padrão de comportamento e aceitação unicamente branco. Através disso, a ideia de branqueamento da sociedade como um todo se torna cada vez mais presente na realidade institucional desse país e o racismo se torna cada vez mais enraizado e mascarado.

A batalha do negro pela afirmação de sua identidade e igual humanidade não acabou. A partir dessa absurda discriminação de raça, ao 
longo da história, o povo negro vem enfrentando diversas dificuldades e inúmeros ataques contra suas crenças.

Com a visão midiática junto com a ideia de que tudo que vem do branco é o certo, as religiões de matrizes africanas passaram a possuir uma imagem negativa perante a sociedade, o que vem gerando inúmeros discursos de ódio e ataques contra seus adeptos (as). Como será mostrado, os discursos de ódio contra as religiões africanas vêm aumentando e numa tentativa de imposição de verdade única sobre o sagrado, essas religiões vêm sofrendo diariamente diversos atentados contra suas casas e contra ao seu povo de santo.

Por mais que estejam garantidos constitucionalmente em nosso país a liberdade de crença e a liberdade de culto, não é o que presenciamos na prática. $\mathrm{O}$ que se tem é a tentativa mascarada constante de cerceamento de direitos dessa parcela da sociedade.

A laicidade estatal há muito tempo vem sendo comprometida através de práticas silenciosas de marginalidade dessas religiões e das tentativas de proibições de expressão do sagrado em suas crenças.

Desse modo, nos deparamos diariamente com situações que comprovam a falta de separação entre Estado e Religião, isto é, o que presenciamos na prática é que por mais que seja um princípio constitucional a laicidade estatal, ainda é possível presenciarmos comportamentos e julgamentos nos quais concepções religiosas e julgadores se confundem. Não há como esperar menos de uma sociedade, na qual o ideal naturalizado de brancura mascara a realidade de privilégios que constitui, bem como e a concepção racista que a fundamenta. Como consequência dessa hegemonia branca majoritariamente católica ou neopentecostal com pensamentos e comportamentos retrógrados que aceita que a sociedade tenha em seu cerne a discriminação racial e religiosa, temos a possibilidade de um ensino confessional em escolas públicas.

Portanto, devido a essa realidade de perseguição e discriminação temos hoje pendente de julgamento a proibição ou não de uma das práticas 
mais tradicionais de muitas das religiões de matrizes africanas, o abate de animais. A partir do momento em que temos o Supremo Tribunal Federal de um país tendo que julgar acerca da legalidade de uma prática religiosa de uma minoria perseguida em toda a sua história, temos que reconhecer que tudo está errado.

As inúmeras tentativas de aniquilamento cultural do negro fizeram com que fosse necessária a busca por medidas legais para frear essa perseguição. A tentativa da federalização dos crimes contra as religiões de matrizes africanas oferece caminhos alternativos para a comunidade negra, que espera que as questões sejam tratadas em consonância com as normas constitucionais e tratados internacionais de proteção de direitos humanos, sem a reiteração das violências secularmente empregadas contra esse segmento.

Portanto, o presente trabalho visa estabelecer a ligação entre as heranças históricas raciais da nossa sociedade relacionadas com o comportamento social do segmento social com mais poder, passando assim por diversas análises desde o comportamento do branco até o genocídio do povo negro. 


\section{CAPÍTULO I - A HERANÇA DA ESCRAVIDÃO}

\section{1 "Sinhô branco também furta, quando faz a escravidão"}

Escravidão: estado de escravo; cativeiro; Servidão; sujeição; falta de liberdade. Escravo: cativo, o que vive em absoluta sujeição a outrem; Súdito de um tirano. Escravatura: tráfico de escravos. Servidões: estado ou condição de servo; dependência; $\underline{\text { escravidão }}^{1}$.

O Brasil, em meados de 1500, tinha como população predominante a indígena que com as futuras guerras e doenças, rapidamente seria dizimada.

Assim, no Brasil colonial, sem metais preciosos, a exploração de cana-de-açúcar se desenvolveu em ritmo acelerado, sendo necessária mais mão-de-obra para trabalho durante um ano inteiro em clima tropical.

Estima-se que entre 1502 e 1850 mais de 9.500 .000 escravos negros foram trazidos da África para o trabalho escravo nas Américas. Dentre esses números, avalia-se a entrada, mais ou menos, de 3.500 .000 a 3.600.000 cativos em terras brasileiras. O Brasil, pelo que se acredita devido à falta de dados, foi responsável pela importação de $38 \%$ dos escravos trazidos para o Novo Mundo durante o período colonial ${ }^{2}$.

A escravidão teve como objetivo a retirada de indivíduos de diferentes nações e territórios para serem transformados em mão-de-obra escrava por um grupo social que se auto classificava como superior ${ }^{3}$.

A porta de entrada para o tráfico negreiro se deu através das grandes navegações. Em média, por exemplo, o trajeto de Angola a Pernambuco era feito em 35 dias, até a Bahia eram necessários 40 dias, enquanto até o Rio de Janeiro levava-se 50 dias. No entanto, essas durações sofriam diversas

\footnotetext{
${ }^{1}$ Dicionário do Aurélio Online - Dicionário Português. 2008-2017.

${ }^{2}$ MATTOSO, Kátia M. de Queirós. Ser escravo no Brasil. Séculos XVI-XIX. Petrópolis, RJ: Vozes, 2016, p.75.

${ }^{3}$ POSSEBON, Roberta Mottin. A reação das religiões de matriz africana no Rio Grande do Sul: conflitos com neopentecostais e defensores dos animais. Pontifícia Universidade Católica do Rio Grande do Sul, 2007. [Pós-Graduação]. p. 22.
} 
variações de acordo com os ventos e tipo de embarcação, podendo uma viagem durar até cinco meses ${ }^{4}$.

Independente do tempo de duração, a travessia era extremamente sofrida. Os navios negreiros eram superlotados, sendo os escravos empilhados ao fundo dos porões como objetos, acorrentados, não havendo espaço ou sequer condições para as necessidades fisiológicas. Nos mesmos porões que dormiam, ficavam ali durante a viagem inteira em um ambiente completamente insalubre, onde o calor e o odor se tornavam insuportáveis.

Nessas longas viagens, as taxas de mortalidades nos navios eram elevadas, mantendo-se entre $15 \%$ a $20 \%$. Os cativos nos navios negreiros se expunham a todos os tipos de riscos, tornando-se especialmente vulnerabilizados frente à morte.

Se para a tripulação a viagem era longa, para o cativo era ainda mais: acorrentado aos ferros e conscientes de estar embarcando para uma viagem sem volta em que cada hora passada significava o alargamento do abismo que o separava de sua terra natal, expondo-o, mãos e pés atados ao opressor estranho e brutal. ${ }^{5}$

Nos mercados dos portos onde se desembarcava os escravos, a venda era feita em pregões ou então de particular para particular. Com a chegada dos cativos se fazia necessário abriga-los em depósitos fixos, como a paróquia comercial de Pilar de Salvador da Bahia. Entretanto, a grande maioria não dispunha, sendo o mercado de escravos a céu aberto, ficando os cativos sujeitos ao mau tempo.

A venda em leilões públicos não se resumia apenas a escravos recém-chegados ao Brasil, mas também em casos de dívidas dos senhores de engenho. Quando os senhores de engenho não conseguiam honrar sua dívida, os primeiros bens a serem tomados eram os escravos que, então, eram vendidos em leilão público.

\footnotetext{
${ }^{4}$ MATTOSO, Kátia M. de Queirós. Op. cit., p. 69.

${ }^{5}$ Ibid. p. 75.
} 
Em suas jornadas, os escravos ficavam sujeitos aos mais variados tipos de castigos que iam desde os açoites públicos nos chamados pelourinhos aos chamados bolos, que consistiam no uso da palmatória.

Obedecer para os escravos significava aprender a língua portuguesa e as práticas cristãs. Mas, acima de tudo, o que realmente importava e demonstrava disciplina era realizar um bom trabalho, em outras palavras, trabalhar em condições extremas, sem alimentação, durante um dia inteiro, até não possuir mais forças para ficarem em pé sem demonstrar qualquer relutância às ordens dos capatazes dos senhores de engenho responsáveis pela organização do trabalho.

Buscando uma maior submissão e obediência, os senhores de engenho buscavam primeiramente inspirar medo. O chicote, o tronco, as correntes, as máscaras de ferro, os ferros e o pelourinho eram muito utilizados como forma de castigo.

Quando se perdia a submissão e lealdade, surgindo rebeliões dentro das fazendas e engenhos, utilizava-se de todos os métodos possíveis de castigo, além dos já citados, era comum marcar os cativos com ferro em brasa, além de mutilações, fraturas, e muitas vezes a contenção nos troncos, onde o negro tinha suas extremidades acorrentadas presas com cadeados.

Aos escravos recém-chegados, cabia ao senhor ou ao capataz a tarefa de ensinar a língua portuguesa. Como havia poucos padres que habitavam dentro das grandes fazendas de engenho e, a partir do século XVIII, não se encontrava mais tantos missionários jesuítas que percorriam o interior para conhecer algumas línguas africanas e catequizar os cativos, o entendimento da língua africana ficou cada vez mais escasso tornando a comunicação entre senhor de engenho e escravos mais restrita.

Os cativos eram obrigados a serem batizados, pelo governo brasileiro, entretanto, a catequização era meramente formal, uma vez que não existia por parte da Igreja Católica uma força efetiva para a conversão, além de que aos escravos era proibido assistir às missas juntos de seus senhores. 
Assim, para os senhores bastava que seus escravos soubessem uma linguagem básica que permitisse entender ordens. Apenas os escravos que possuíam contato direto com os senhores, principalmente os domésticos, é que conseguiam aprender a língua portuguesa e seus filhos, criados dentro das casas grandes, com o passar do tempo, tinham como português sua língua principal, tornando-se a língua africana secundária e não muito desenvolvida ${ }^{6}$.

A educação dos escravos em escolas era proibida no Brasil inclusive para os alforriados ${ }^{7}$. Os poucos senhores e padres que ensinavam os escravos a ler e escrever eram considerados transgressores. Os escravos trazidos para o Brasil continuavam desconhecidos, sem sua história contada através de suas visões, sem seus sofrimentos documentados, como se não passassem de meros fantasmas na realidade brasileira.

O mesmo senhor que precisava se fazer compreender para dar ordens, através de uma linguagem básica, e organizar os trabalhos, desejava também que seus cativos compreendessem os rudimentos da religião católica para ensinar a rezar. Durante a escravidão, a sociedade contou com o apoio da Igreja Católica para ensinar aos escravos as virtudes da submissão, resignação e a obediência à ordem estabelecida. Consequentemente, obedecer para o escravo significava aprender os rudimentos do português e das práticas católicas.

$\mathrm{Na}$ quase totalidade dos casos de fuga, os escravos eram devolvidos ${ }^{8}$. As recompensas postas por suas cabeças eram muito atraentes para aqueles que viviam de delações e caça a escravos fujões, enquanto isso, o medo do castigo apavorava aqueles que pensassem em acolher um fugitivo.

Para aqueles cativos que não se adaptavam a nova realidade, restavam lhe poucas opções. Dentre suicídio e assassinato, a fuga era mais utilizada. Fuga esta, que não consistia em apenas fugir do seu senhor ou do

\footnotetext{
${ }^{6}$ Ibid. p. 139.

${ }^{7}$ Ibid. p. 139.

${ }^{8}$ Ibid. p. 179.
} 
árduo trabalho, mas uma fuga de um modo de vida imposto a ele, sem direitos e de puro sofrimento.

O tráfico negreiro perdurou por séculos, ultrapassando o período de três séculos, muitas vezes de forma clandestina a partir da continuidade da prática mesmo após a proibição oficial em 1830.

\subsection{O medo do branco ao silêncio do negro}

Dos poucos documentos oficiais que existem sobre o período da escravidão difícil encontrar aqueles que são através das palavras dos escravos, boa parte do que tivemos acesso até hoje foi construído através da visão do homem branco, que documentou o período pelo seu olhar.

O olhar do branco sobre o negro é, na realidade, um testemunho que diz muita coisa, mas o escravo não pôde dizer diretamente, assim só podemos tentar conhecê-lo por meio de seus comportamentos ${ }^{9}$.

A escassez de informações e documentos a respeito dificultam um estudo mais aprofundado de como se deu exatamente o conflito entre as religiões de matrizes africanas com a religião católica na época colonial do Brasil.

Mesmo com poucos estudos e informações conflitantes e dispersas, é possível perceber que o interesse do branco a respeito das crenças dos cativos apenas ocorria quando a religião dos escravos, de algum modo, o incomodava, como por exemplo o batuque dos tambores ${ }^{10}$.

Os cultos africanos certamente existiram no Brasil colonial, cultos estes escondidos e intermitentes, que procuravam escapar da repressão e com o qual o branco só demonstrava interesse quando perturbada a paz pública, como por exemplo, em casos do barulho trazidos pelos cantos e batuques de tambores.

\footnotetext{
${ }^{9}$ Ibid. p. 139.

${ }^{10}$ Ibid. p. 175.
} 
Entretanto, os casos de perseguições a negros cativos por acusações de feitiçaria eram inúmeros. As cerimônias, os rituais e até o uso de "patuás" ou "mandigas" foram confundidos com rituais de feitiçaria, considerado crime e proibida pelas Ordenações Filipinas.

Mesmo sendo seus rituais religiosos realizados dentro de recintos fechados, em locais isolados, estes não estavam livres das invasões às suas casas. Dentre os diversos medos em relação ao desconhecido, aos rituais africanos, o medo em relação às ervas e raízes utilizadas se destacavam, uma vez que se tinha a crença de que os "feiticeiros" as usavam para feitiços contra seus senhores, desejando suas mortes.

No exercício de suas crenças, os africanos e seus descendentes presenciaram desde condenações inquisitoriais, no século XVIII, a intensas perseguições e processos criminais durante o século XIX. Na cidade do Rio de Janeiro, capital do Império e da futura República, as invasões às casas de dar fortuna e aos candomblés foram executadas com rigor pelas autoridades. Alguns objetos encontrados nos espaços religiosos eram considerados os principais indícios do "crime": manipansos, animais mortos, pedras e, especialmente ervas e raízes que, misturadas com terra, eram conhecidas como "mandigas". Os responsáveis pelos "antros de feitiçaria" tiveram complicações com a justiça. ${ }^{11}$

Durante o período imperial, o Estado perseguiu severamente todas as práticas religiosas contrárias ao catolicismo, religião oficial do império proclamada pela Constituição de 1824, "em nome da Santíssima Trindade". Embora existisse a liberdade de crença, a liberdade de culto por sua vez era inexistente. Mesmo com o artigo $5^{\circ}$ da Constituição permitindo o culto de diferentes religiões dentro do ambiente doméstico, na prática apenas era permitido o culto católico.

Art. 5. A Religião Catholica Apostolica Romana continuará a ser a Religião do Imperio. Todas as outras Religiões serão permitidas com seu culto domestico, ou particular em casas para isso destinadas, sem fórma alguma exterior do Templo ${ }^{12}$.

\footnotetext{
${ }^{11}$ COSTA e GOMES, Valéria e Flavio. Religiões negras no Brasil da escravidão à pósemancipação. São Paulo: Selo Negro, 2016, p. 170.

$12<$ http://www.planalto.gov.br/ccivil_03/constituicao/constituicao24.htm> Acesso em 3 de jun. 2017.
} 
Conquanto a Constituição de 1824 em seu artigo 179, inciso V, determinasse que não pudesse haver perseguição religiosa, abria a exceção para casos de distúrbio da Moral.

Art. 179. A inviolabilidade dos Direitos Civis, e Politicos dos Cidadãos Brazileiros, que tem por base a liberdade, a segurança individual, e a propriedade, é garantida pela Constituição do Imperio, pela maneira seguinte.

V. Ninguem póde ser perseguido por motivo de Religião, uma vez que respeite a do Estado, e não offenda a Moral Publica ${ }^{13}$.

O que mais poderia caracterizar ofensa a Moral Pública que práticas de rituais religiosos de matrizes africanas? O medo do desconhecido e a hegemonia do branco com suas crenças fizeram com que a sociedade passasse a entender os rituais africanos como pagãos e práticas de feitiçaria devendo sempre ser oprimidas quando ofendesse a chamada Moral Pública, termo este criado pela elite dominante, ou seja, por brancos, numa sociedade branca, cuja religião oficial, à época, era praticada exclusivamente por brancos excepcionando àqueles que a praticavam por mera imposição do medo.

Consequentemente, os adeptos das religiões africanas passaram a praticar seus cultos e seus rituais em locais fechados. Posteriormente, com o advento do Código Criminal do Império de 16 de dezembro de 1830, foi institucionalizada a punição para aqueles que celebrassem qualquer tipo de culto que não fosse a religião oficial do império, isto é, todos aqueles que não cultuavam Deus como os católicos, poderiam ser enquadrados nos crimes tipificados no Código.

\footnotetext{
CAPITULO I

OFFENSAS DA RELIGIÃO, DA MORAL, E BONS COSTUMES

Art. 276. Celebrar em casa, ou edificio, que tenha alguma fórma exterior de Templo, ou publicamente em qualquer lugar, o culto de outra Religião, que não seja a do Estado.

Penas - de serem dispersos pelo Juiz de Paz os que estiverem reunidos para o culto; da demolição da fórma exterior; e de multa de dous a doze mil réis, que pagará cada um ${ }^{14}$.
}

${ }^{13}$ Ibid. Acesso em 3 de jun. 2017. 
Pode-se notar, assim, que a liberdade de culto era apenas conferida àqueles da religião cristã, sejam congregações cristãs estrangeiras e os dos brancos já residentes nas colônias.

O negro mesmo liberto não encontrou na lei proteção e amparo para a livre manifestação de suas crenças. Como para a sociedade na época, os poderes espirituais do negro eram considerados magia ou feitiçaria, se fazia necessário e imprescindível a proteção da sociedade branca contra qualquer mal que poderia advir das práticas das crenças religiosas negras.

\subsection{Sincretizados na fé: entre o santo e batuque}

Nesse cenário, de grande repressão e proibições de suas práticas, durante a escravidão no Brasil, os negros se viram acuados e sem ter como cultuar suas crenças sem que fossem presos ou castigados por tais práticas.

Numa tentativa de preservação dos princípios e práticas religiosas, através de uma conciliação entre as religiões com o catolicismo, deu-se origem a diversas manifestações religiosas sincréticas que são visíveis até hoje.

O sincretismo religioso nada mais é que o contato entre diferentes tipos de crenças, que fundidas dão origem a uma nova religião com características de suas originárias. Porém, o sincretismo, observado pelo ponto de vista do oprimido, não passa de uma releitura de significados, estando prevalecente aqueles da religião predominante, num processo de opressão cultural, cuja principal característica se faz a ideia de superioridade de raças, culturas e sociedades. ${ }^{15}$

Nessa lógica, não havia outra solução se não a incorporação de características do catolicismo àquelas religiões que the eram distintas. Durante o processo de catequização das terras brasileiras, foi de

\footnotetext{
$14<$ http://www.planalto.gov.br/ccivil_03/leis/lim/LIM-16-12-1830.htm> Acesso em 3 de jun. 2017.

${ }^{15}$ SOARES, Afonso Maria Ligorio. Sincretismo afro-católico no Brasil: lições de um povo em exílio. Revista de Estudos da Religião, n³. Pontifícia Universidade Católica de São Paulo. 2002, p 51.
} 
responsabilidade dos donos de engenho a educação religiosa, não sendo permitido qualquer culto que não fosse o católico, ou seja, além da escravidão física, os negros foram submetidos à escravidão espiritual/epistêmica.

Os negros eram obrigados pela Igreja Católica a serem batizados, mas não existia por parte da Igreja um empenho efetivo na conversão de fato.

Essa realidade de perseguição fez com que os negros utilizassem a religião como uma forma de resistência a supremacia branca. A partir disso, iniciou-se o processo sincrético em terras brasileiras havendo a convivência de santidades católicas com suas divindades, muitas vezes, utilizando uma mesma representação.

Os batuques inocentes, as "orgias" ou mesmo uma mera consulta "inevitável" com uma negra curandeira podem alcançar significados diversos. Neste trabalho, significados são claros: foram mecanismos de resistência consciente ou não contra a imposição de uma regra e de uma cultura que visava destruir a memória e as práticas africanas que teimavam em se preservar em meio a um ambiente tão hostil. ${ }^{16}$

O sincretismo foi usado como uma arma pelos oprimidos contra a cultura esmagadora dos povos escravizadores. Esse trabalho de "catequese" realizado pelos senhores de engenho, como já dito, na verdade, não passou de um processo de violência simbólica para os negros que recebiam a religião cristã como única possibilidade de verdade e que resistiam a isso escondendo e disfarçando suas próprias crenças.

Passou-se, então, a se adotar as imagens católicas e as cultuar, para, sob as invocações de santos católicos, poder adorar seus orixás e demais divindades.

Com efeito, era 'tradicional' entre os centro-africanos formar novos grupos religiosos e aceitar novos rituais, símbolos, crenças e mitos. Portanto, eles não tinham de abandonar sua religião, quando escolhiam venerar a imagem de um

\footnotetext{
${ }^{16}$ COSTA e GOMES, Valéria e Flavio. Op. cit., p. 54.
} 
santo católico. Como na África, simplesmente adorava a estátua como um símbolo novo. ${ }^{17}$

Nas senzalas, para que se fosse possível cultuar os orixás e voduns, os negros passaram a usar, como disfarce, altares com imagens de santos católicos. Mesmo usando imagens de santos católicos, seus rituais e cultos foram perseguidos pela Igreja Católica, que os viam como curandeirismo e bruxaria, práticas consideradas crimes e severamente proibidas pelas Ordenações Filipinas, passando a serem vistas como demoníacas.

Seus cultos eram vistos como um atentado contra os bons costumes e a moralidade, e à própria fé. As reuniões foram proibidas, junto com seus rituais, danças e tambores.

As figuras de seus orixás passaram, então, a ser representadas por santos católicos, herança essa que é possível encontrar até os dias de hoje em cultos de religiões como a umbanda e em algumas casas de candomblé.

Apenas para vias de ilustração, o quadro abaixo mostra o sincretismo existente entre as religiões, no qual os orixás possuem a mesma figura religiosa representada apenas por outra imagem no catolicismo.

\begin{tabular}{|c|c|}
\hline Oxalá & Jesus Cristo \\
\hline Ogum & $\begin{array}{c}\text { São Jorge / São Sebastião } \\
\text { (dependendo da região do país) }\end{array}$ \\
\hline Xangô & $\begin{array}{c}\text { São Jerônimo } \\
\text { São Pedro } \\
\text { São João }\end{array}$ \\
\hline Oxossi & $\begin{array}{c}\text { São Sebastião / São Jorge } \\
\text { (dependendo da região do país) }\end{array}$ \\
\hline
\end{tabular}

${ }^{17}$ KARASCH, Mary. A vida dos escravos no Rio de Janeiro (1808-1850). São Paulo: Companhia das Letras, 2000, p. 355. 


\begin{tabular}{|c|c|}
\hline Omolú/Obaluaiê & $\begin{array}{c}\text { São Lázaro } \\
\text { São Roque }\end{array}$ \\
\hline Logum Edé & Santo Expedito \\
\hline Exu & Santo Antônio de Pemba \\
\hline Oxum & $\begin{array}{c}\text { Nossa Senhora Das Candeias } \\
\text { Iemanja }\end{array}$ \\
\hline Iansã/Oya & $\begin{array}{c}\text { Nossa Senhora Dos Navegantes } \\
\text { Nossa Senhora da Conceição }\end{array}$ \\
\hline Ibeji & Santa Bárbara \\
\hline Nanã Buruquê & Nossa Senhora Sant'Ana \\
\hline & \\
\hline
\end{tabular}

Apenas utilizando-se de violenta imposição, o sincretismo teria sucesso. Da necessidade do negro de proteger suas crenças religiosas contra a supremacia da sociedade dominante ${ }^{18}$, surgiu o sincretismo religioso.

Mesmo com a tentativa de difusão por uma sociedade hegemônica branca da ideia de que essa fusão entre as religiões de matrizes africanas e a católica se deu naturalmente, numa compreensão recíproca, de igual para igual, não é o que ocorreu. Conforme alerta Abdias Nascimento: ${ }^{18}$ NASCIMENTO, Abdias do. O genocídio do negro brasileiro. Processo de um Racismo
Mascarado. Rio de Janeiro: Editora Paz e Terra S/A, 1978, p. 108. 
Para manter uma completa submissão do africano o sistema escravista necessitava acorrentar não apenas o corpo físico do escravo, mas acorrentar também seu espírito.

Com a ajuda de um sistema de pensamento ocidental imposto através da coerção e do emprego de violência física, foi também privado o negro do direito a crença sendo determinado como padrão aceito apenas a religião católica.

Assim, só poderia, então, ser chamado de sincretismo religioso apenas o fenômeno de relação das religiões de matrizes africanas entre si e entre elas e as crenças religiosas indígenas brasileiras. $\mathrm{O}$ encontro dessas religiões, diferentemente com a relação do catolicismo, se deu de forma natural, no qual a mistura desses dois sistemas espirituais deu origem a novas formas de expressões religiosas com características de ambos os lados. ${ }^{19}$ Nesse processo, a fé é respeitada como igualmente autêntica tanto pelas religiões de matrizes africanas, bem como as indígenas.

Essa postura de imposição de comportamento, pensamento e crença não passa de tentativa de uma sociedade branca escravista de apagar qualquer herança cultural do negro, numa tentativa de transformá-lo apenas em objeto na história desse país, sendo sua herança, em tese, apagada com facilidade.

\footnotetext{
${ }^{19}$ NASCIMENTO, Abdias do. Op. cit., p. 110.
} 


\section{CAPÍTULO II - BRANQUITUDE}

\subsection{Do narcisismo do branco}

Conforme retratado no capítulo anterior, durante toda a história do Brasil, o negro teve seu papel na sociedade restringido à marginalidade. Numa sociedade de maioria branca, cuja realidade escravista colocava o negro numa posição de inferioridade, o surgimento do racismo e de uma ideologia de comportamento exclusivamente branca era inevitável. Como herança, nossa sociedade ainda carrega essa errônea concepção de superioridade do branco em relação ao negro, sendo aceitável apenas o padrão comportamental dessa parcela da sociedade. Essa realidade de hegemonia branca e de superioridade de raça se estende até hoje.

Durante muitos anos, estudiosos de diversos ramos vêm reproduzindo pesquisas sobre o racismo dentre suas inúmeras formas de demonstração. $\mathrm{O}$ estigma do negro, suas consequências trágicas nas vidas dessas pessoas, a solidão, a dor, são temas tratados corriqueiramente ao se analisar a presença do negro na construção de sociedades.

Porém, uma pergunta sempre esteve ali presente, mas sempre ignorada, e os brancos? Como se percebem diante do racismo? Como se enxergam diante da opressão permanente do negro presente no seu dia-adia? Por que não há uma participação significativa dos brancos nos movimentos negros em busca de igualdade? A que se dá a invisibilidade do branco? A que se dá a incapacidade do branco se entender enquanto ser racializado?

Impossível negar que as desigualdades raciais ainda se encontram persistentes, presentes e impactando a relação entre negros e brancos. Toda grande sociedade tem seu funcionamento dependente de instituições. Instituições que funcionam basicamente sob a perspectiva do segmento 
social dominante. O pensamento e o comportamento dos segmentos sociais regem a forma de organização das instituições dentro de uma sociedade.

Difícil não encontrar instituições conservadoras na sua essência, já que, como dito, estas reproduzem comportamentos e indivíduos dos segmentos sociais dominante.

E, afinal, quem são aqueles que integram esse segmento social dominante?

A semelhança entre o perfil das pessoas que ocupam lugares de prestígio e poder nas instituições, majoritariamente masculino e branco, denuncia mais do que a história de racismo no Brasil e uma espécie de "pacto nascísico" nos processos de acesso a esses ligares. Denuncia a prevalência de uma perspectiva, de uma visão de mundo e de interesse de determinado grupo, o que configura o que chamamos de branquitude. ${ }^{20}$

A branquitude e a masculinidade hegemônica nos postos de poder fazem com que seja reproduzido na sociedade um certo padrão de comportamento e aceitação exclusivo.

Essa visão de mundo majoritariamente branca e masculina não passa de uma construção social e histórica que se evidencia no cotidiano das instituições, da mídia e dos altos cargos de poder.

Isso proporciona identificações e o chamado "narcisismo" que ocorre na classe dominante ao se conectar apenas com aqueles que the convém chamar de "iguais", desprezando, menosprezando e tratando muitas vezes com violência aqueles considerados inferiores, sejam eles mulheres, membros da comunidade LGBT, negros ou pobres.

Nesse sentido, ao se analisar as implicações raciais dessas relações, fica evidente que a identidade racial é o principal separador e auxiliador de identificação entre os que pertencem ao poder e aos "outros".

Assim, a branquitude começa a ser construída a partir de um aparato de poder, em que os brancos entendem por sua identidade racial como

\footnotetext{
${ }^{20}$ BENTO, Maria Aparecida; SILVEIRA, Marly; NOGUEIRA, Simone. Identidade, Branquitude e Negritude. São Paulo: Casapsi Livraria e Editora Ltda, 2014. p. 17.
} 
norma e padrão, sendo todos os indivíduos que não se enquadram nesse padrão considerados como diferentes, exóticos e inferiores.

O racismo para o branco funciona como uma forma de manter um status de superioridade que não seria possível se todos fossem reconhecidos como iguais.

Juntando essa concepção de branquitude com o racismo o que se tem é que toda essa concepção de superioridade não passa de uma construção social e histórica que possibilita e legitima a afirmação de discursos de ódio e inferioridade.

Como é possível tratar do racismo ou de seus efeitos sem ao menos se comprometer à análise? É como se existisse um acordo entre os brancos para não se reconhecerem como peça importante também nessa discussão.

O racismo não é apenas um problema do negro, é um problema de uma sociedade racista, sexista, classista, cristã e heteronormativa, isto é, é um problema, acima de tudo, também, do branco. A herança da escravidão é perceptível a partir da existência de um contexto atual que insiste em reforçar a inferioridade do negro ${ }^{21}$.

No Brasil, essa situação de extrema desigualdade racial se dá graças a um cenário onde brancos e negros interagem, mas para que se possa manter os padrões já construídos, embora exista a presença de ambos, essa presença se faz de forma completamente desigual, estando cada um em lugares diferenciados e hierarquizados na sociedade.

Destaca-se dentro desse debate a eterna questão entre a discussão de raça e classe. Vemos claramente dentro da nossa realidade brasileira que há a marcante concepção de que políticas sociais para negros seria a mesma coisa que política social para pobres. A maior parte da população brasileira hoje é composta por negros representando cerca de 53,6\%, resultado da

${ }^{21}$ PIRES, Thula Rafaela. Criminologia crítica e pacto narcísico: por uma crítica criminológica apreensivel em pretuguês. Revista Brasileira de Ciência Criminais, São Paulo, n. 135, set. 2017. 
combinação de $45 \%$ de pardos e $8,6 \%$ de pretos, (IBGE 2014) (I2 $^{2}$ e dentro da camada mais pobre da população, os negros se representam cerca de $70 \%{ }^{23}$.

A partir disso, é preciso atentar que, por mais que os programas socais venham desempenhando importante papel para diminuir essa realidade, os espaços de poder, hoje, continuam dominados por brancos, sendo possível observar uma resistência à implantação de políticas afirmativas específicas voltadas ao segmento negro.

Enquanto essa importante mudança no poder não ocorre, não se deve parar de buscar uma análise mais complexa e que busque a transformação das hierarquias e padrões vigentes entre identidade racial e poder.

O debate atual que vem sendo travado intensamente, mas, infelizmente, ainda não na força que se faz necessário, sobre reforma política pode vir a melhorar essa situação de concentração de poder nas mãos de homens brancos ao propiciar a criação de ferramentas que assegurem uma ampliação da representação política de outros grupos historicamente vulnerabilizados em todas as esferas de poder.

As barreiras impostas aos processos de mudança na distribuição do poder no espaço institucional são muito profundas e não cedem com facilidade.

Mesmo dentro de um contexto em que proliferam discursos sobre a igualdade, as barreiras ainda são muito fortes e a resistência permanece, sendo levantados para debate questões como as cotas no ensino superior, que não deveriam ser o alvo central já que são uma política social como consequência da realidade brasileira de segregação.

Essa dimensão profundamente ideológica da branquitude expressa e mascara a realidade, e só tem sentido em sociedade divididas por conflitos sociais. Aí sua função será ocultar o conflito, apregoar o povo unido e mascarar a dominação. ${ }^{24}$

\footnotetext{
${ }^{22}$ Pesquisa Nacional, por amostra em domicílios. Síntese de indicadores 2014. IBGE. Disponível em: <https://biblioteca.ibge.gov.br/visualizacao/livros/liv94935.pdf> Acesso em 12 de out. 2017 $23<$ https://ww2.ibge.gov.br/home/presidencia/noticias/12062003indic2002.shtm> Acesso em 12 de out. 2017

${ }^{24}$ BENTO, Maria Aparecida; SILVEIRA, Marly; NOGUEIRA, Simone. Op. cit., p. 18.
} 
A maior luta hoje se faz através do combate à herança histórica da branquitude, isto é, entender o funcionamento da branquitude permite perceber que a discrepância dos papéis exercidos pelo negro e pelo branco na sociedade são consequência de uma carga histórica de supremacia branca reproduzida incessantemente através de geração a geração.

\subsection{Da visão do branco}

Historicamente, o medo do branco tem suas raízes históricas. Durante a transição do período escravocrata para a abolição formal pairava uma questão essencial no ar: o que fazer com os negros após a ruptura entre senhor de engenho e escravo?

Mesmo aqueles que, durante o período da escravidão, eram livres estavam sujeitos a ter seus direitos limitados, uma vez que a sociedade era dominada por uma elite branca. Os negros traziam no corpo a marca de um passado na condição de escravos o que fazia com que mesmo livres fossem tratados com desprezo e violência.

A definição inferiorizante do negro perdurou mesmo depois da desagregação da sociedade escravocrata e da sua substituição pela sociedade capitalista, regida por uma ordem social competitiva. Negros e brancos viam-se e entreviam-se através de uma ótica das relações sociais. O negro era paradoxalmente enclausurado na posição de liberto: a ele cabia o papel do disciplinado - dócil, submisso e útil enquanto o branco agia com autoritarismo, por vezes paternalista, que era característico da dominação senhorial..$^{25}$

Essa ideia do diferente, do inferior, do subalterno está tão enraizado na nossa realidade que os brancos tomam sua identidade por norma padrão a ser seguida. Identidade essa que muitas vezes é invisível a ponto de não se ter uma reflexão do que significa ser branco no cotidiano de uma sociedade racista.

${ }^{25}$ SOUZA, Neusa. Tornar-se negro ou As Vicissitudes da Identidade do Negro Brasileiro em Ascensão Social. Rio de Janeiro: Editora Graal Ltda., 1993, p. 20. 
Ao grupo dominante foram reproduzidos e compartilhados os medos e receios em relação à convivência em pé de igualdade com o grupo dominado, aprisionado em estigmas e estereótipos de subalternidade que quanto mais se consolidavam no imaginário social, mais adquiriram no senso comum o status de verdadeiro (AZEVEDO, 1987). ${ }^{26}$

O silêncio, a omissão e a distorção do lugar do branco dentro de uma sociedade completamente desigual têm um papel fundamental na construção do ideal de condição humana. Por que será que a mídia ao representar um modelo respeitável de família, um adulto, ou até mesmo um jovem, usa quase que exclusivamente o branco?

Não é surpreendente o fato de que tudo que fazemos referência pejorativa, usamos negro como adjetivo. Esse daltonismo e essa cegueira caracterizam o estranho. A cegueira do branco em não assumir seu papel de predominante em detrimento do negro perpetua a segregação.

O sujo está associado ao negro: à cor, ao homem e à mulher negros. A linguagem gestual, oral e escrita institucionalizada o sentido depreciativo do significante negro: o "Aurélio", por exemplo - para citar apenas um dos nossos mais conceituados dicionários - vincula ao verbete NEGRO os atributos sujo, sujeira, entre dez outros de caráter pejorativo. ${ }^{27}$

Essa concepção tão enraizada em nosso cotidiano, devagar e de forma mascarada, faz com que seja aceito a colocação do negro no seu "devido" lugar de inferioridade. Cabe aqui destacar que não só o negro ocupa esse lugar, mas todos os grupos que diferem da brancura.

Enquanto não há uma conscientização acerca da supremacia branca na sociedade e os privilégios que dela surgem, os privilégios da brancura como condição ideal de ser humano são mantidos, o que faz com que negros sem qualquer reconhecimento sobre seus valores culturais e sociais encontrem no processo de branqueamento uma forma fictícia de integração social.

\footnotetext{
${ }^{26}$ PIRES, Thula Rafaela. Op. cit.

${ }^{27}$ SOUZA, Neusa. Op. cit., p. 18.
} 
Essa ideologia de branqueamento presente na sociedade brasileira assimilada pela população fez com que se tornasse essencial para a participação das relações sociais a assimilação do comportamento dos brancos.

O racismo frequente na sociedade brasileira só faz com que se construa cada vez mais uma sociedade em que a própria população não consegue enxergar sua realidade através do espelho e aceitar que somos sim uma população desarmônica.

A grande dificuldade do branco em enxergar que vive numa realidade de privilégio se dá, principalmente, pelo medo do que acarretaria passar a enxergar todos como iguais o que isso acarretaria.

O medo da perda do emprego, da perda do poder, da perda do status, faz com que essa noção de inferioridade do outro por sua raça seja reproduzida e ensinada de maneira constante de geração em geração, visando uma autoafirmação de raça superior, ainda que esse comportamento não ocorra de forma assumida/intencional.

A branquitude informa o papel que o negro deve representar na sociedade, como está explícito não só no racismo escancarado, na noção de inferioridade, mas também ao se construir na sociedade a noção de que todos devemos ser como brancos, isto é, a sua vontade de ascensão de vida, classe social, emprego, felicidade, não se dá apenas por seu desejo interno próprio, mas sim pelo desejo de atingir o patamar que o branco um dia chegou.

A aspiração por uma realidade de privilégios não foi construída em cima do pressuposto que todos devemos buscar ascensão social pelo fato de que somos iguais e podemos sim ocupar os mesmos cargos, mas, na verdade, pela busca incessante de uma realidade inacessível, na qual apenas brancos fazem parte.

A hegemonia hierarquizada do branco, da identidade branca faz com que o negro seja impedido de formar uma identidade negra positiva, baseada no resgate de valores individuais e coletivos em nome de uma nova 
percepção de si e do mundo social, perpetuando valores depreciativos e estereotipados que se arrastam ao longo dos anos. ${ }^{28}$

No negro, a marca da diferença, ferro em brasa que o separa do branco, é vivida não só a nível do seu comportamento externo: ele reedita essa desigualdade, introjetada no seu universo psíquico, quando, ao conviver com outro negro, seu semelhante, reproduz o ritual de separação ${ }^{29}$.

Hoje, o normal na nossa sociedade é a concepção de que são os negros que ocupam cargos inferiores ou melhor, quase não ocupam cargos de poder, restando apenas aqueles serviços que o branco, que se afirma como evoluído e informado, não deve ocupar por ser superior.

$\mathrm{O}$ que representaria o negro nessa estrutura? $\mathrm{O}$ feio, o ruim, o exótico, o mau cheiroso, o sensitivo são as representações mais comuns do negro. Todas elas excluem o negro na relação dos significantes e da possibilidade de ressignificar seu lugar material e simbólico na história do Brasil.

Diversos estudos são feitos acerca da escravidão, acerca da carga que o povo negro vem sofrendo ao longo dos anos numa realidade de sociedade completamente desigual, mas o que realmente é feito, hoje, por parte de todos, em concepção do papel de cada um na cadeia, para remediar toda a diferença e sofrimento a que todos sabemos que o negro foi submetido? Muito pouco ou quase nada. Raramente nos deparamos com brancos dispostos a quebrar esses paradigmas e instaurar políticas de conscientização de sua condição de ser racializado e dos impactos de seus atos na perpetuação das desigualdades raciais.

É a estética branca que define padrões, o feio o bonito, os lugares a serem frequentados, o poder e as tomadas de decisões. E é exatamente essa autoridade que possui o consenso legitimador dos padrões ideológicos que

\footnotetext{
28 JESUS, Camila. Branquitude x Branquidade: uma análise conceitual do ser branco. Encontros baiano de estudos em cultura.

${ }^{29}$ SOUZA, Neusa. Op. cit., p. 27.
} 
discriminam uns em detrimento de outros. ${ }^{30}$ Sob quaisquer nuances, em qualquer circunstância, branco é o modelo a ser escolhido.

Assim, "os traços que poderiam caracterizar o negro como superior são aqueles que simbolizam uma verdadeira inferioridade e que definem 'a besta", 31

Numa sociedade de classes onde os lugares de poder e tomada de decisão são ocupados por brancos, o negro que pretende ascender lança mão de uma identidade calçada em emblemas brancos, na tentativa de ultrapassar obstáculos advindos do fato de ter nascido negro. ${ }^{32}$

\subsection{O racismo institucional: dos privilégios}

Por racismo institucional é possível compreender a ação em nível organizacional, independentemente da intenção de discriminar, mas destacando o impacto negativo e desproporcional dessa estrutura sobre certos grupos.

A discriminação nas instituições nem sempre é palpável, podendo, muitas vezes, estar disfarçada sem que seja possível enxergar a verdadeira finalidade.

As práticas aparentemente neutras na maioria dos casos refletem ou perpetuam o efeito da discriminação enraizada no comportamento da população.

Como consequência, essas práticas trazem em si um significado muito maior e intrínseco a suas essências. Ser branco no Brasil e no mundo acarreta situações de vantagens em relação aos não brancos.

$\mathrm{Na}$ sociedade brasileira, os indivíduos, querendo ou não, são classificados racialmente logo que nascem. Àqueles classificados socialmente como brancos

\footnotetext{
${ }^{30}$ SOUZA, Neusa. Op. cit., p. 29.

31 FERNADES, F. O Negro no Mundo dos Brancos. São Paulo: Editora Difusão Européia do Livro, 1972, p. 206.

${ }^{32}$ SOUZA, Neusa. Op. cit., p. 73.
} 
recaem atributos e significados positivos ligados à identidade racial à qual pertencem, tais como inteligência, beleza, educação, progresso etc $^{33}$.

Nesse contexto, a pergunta a ser feita é sobre como os brancos agem para que estes privilégios sejam mantidos e perpetuados ou melhor o que faz com que grande parte dessa parcela da sociedade não os perceba ${ }^{34}$.

A discriminação dentro de instituições tem um enorme caráter rotineiro, aqueles que a praticam não percebem, na maior parte do tempo, que discriminam, restando essa ideia tão naturalizada dentro do meio corporativo. O racismo institucional acima de tudo é um processo histórico e que ocorre de forma estrutural.

Ou seja, o racismo possui várias caras e inúmeras dimensões, crescendo em territórios não esperados, afetando a adoção e o desempenho das políticas de promoção de igualdade racial $^{35}$.

Para mudar esse quadro, se faz necessária uma política de combate à discriminação institucional e para isso, ela deve estar apoiada em valores primordiais à criação de qualquer sociedade, na igualdade e na busca pela justiça sendo sempre conectadas à responsabilidade social de cada instituição.

A análise do comportamento das instituições é primordial para que essas políticas funcionem. No sentido de garantir e propiciar a igualdade, deve-se começar pelos cargos chaves do poder público e privado. A ausência de negros nestes postos é gritante e não pode mais ser naturalizada. A hegemonia racial branca, masculina e heteronormativa em lugares de comando deve ser questionada.

A alteração do quadro no que tange às relações de poder exige a criação de ferramentas legais e regulatórias para lograrmos a ampliação da representação política de negros e negros nas instâncias municipais, estaduais e federais. ${ }^{36}$

\footnotetext{
${ }^{33}$ SCHUMAN, Lia Vainer et al. Identidade, Branquitude e Negritude. São Paulo: Casapsi Livraria e Editora Ltda, 2014, p. 121.

${ }^{34}$ Ibid. p. 122.

${ }^{35}$ BENTO, Maria Aparecida; SILVEIRA, Marly; NOGUEIRA, Simone. Op. cit., p. 17.

${ }^{36}$ Ibid. p. 29.
} 
A indiferença não pode mais ser tolerada. O comportamento reincidente e absurdo das instituições de seleção para cargos de poder ser um único padrão, homem branco, deve ser ultrapassado.

A realidade de negros nos cargos de poder como exceção deve ser convertida, e, para isso, não bastam somente políticas de combate ao racismo institucional apenas no mercado, mas sim, uma reestruturação da sociedade como um todo. Somos todos iguais e não é a cor da pele que diferencia o potencial do individuo. 


\section{CAPÍTULO III - "NAS LUTAS, NAS BATALHAS. SIM, VOU NO TERREIRO PRA BATER O MEU TAMBOR” - AS RELIGIÕES DE MATRIZES AFRICANAS NO BRASIL}

\subsection{O surgimento dos terreiros: a legalização das casas}

Conforme apontado no primeiro capítulo, durante o período escravista, no Brasil, a população negra representava grande parte da sociedade brasileira. A população negra brasileira durante esse período, incluindo africanos, crioulos, pardos e negros libertos ou escravos, tinha como tendência se juntar em regiões onde a predominância era a não branca. $^{37}$

As chamadas "cidades negras" tinham considerável concentração de população afrodescendente, entre livres, libertos e escravizados ${ }^{38}$.

As religiões de matrizes africanas sempre tiveram um papel importante no surgimento desses aglomerados urbanos negros durante todo o período histórico brasileiro, não apenas no período colonial e imperial do Brasil.

Mesmo sendo proibidas nos Códigos Criminais do Império e associadas à feitiçaria, curandeirismo e pejorativamente como macumba, estas religiões não só sobreviveram a todos os tipos de perseguição, como, diga-se de passagem, ainda sobrevivem como matrizes históricas e culturais da nossa sociedade.

Porém, mesmo com todos os esforços para a perpetuação de suas tradições, o sincretismo assimilacionista de vários de seus elementos culturais e de fé com elementos católicos representaram para muitos a busca eterna de afirmação e possibilidade de culto.

\footnotetext{
${ }^{37}$ Revista do Programa de Pós-Graduação em Sociologia da UFPE, v.2, n. 20, 2014. Disponível em: <http://www.revista.ufpe.br/revsocio/index.php/revista/article/view/391/326> Acesso em 17 de out. 2017

38 Ibid. Acesso em 17 de out. 2017
} 
As religiões de matrizes africanas representam e apresentam-se como uma resistência política e cultural à imposição de um comportamento exclusivamente branco, no qual apenas as crenças e religiões que refletem os padrões normativos desse seguimento da sociedade podem ser aceitos como verdade única.

Uma das maiores lutas hoje dos movimentos negros se dá através da valorização das religiões de matrizes africanas como patrimônio histórico e cultural, não apenas em uma região específica, mas sim em patamares nacionais. O que, infelizmente, é muito difícil numa sociedade majoritariamente branca que insiste em não enxergar seus privilégios e em não aceitar a carga histórica negra que esse país carrega na sua origem.

Uma realidade de discriminação e segregação promove a imagem de inferioridade do negro não apenas no aspecto individual, mas também na formação de seu papel e presença na sociedade, que se manifesta escancaradamente nas irregularidades, ilegalidades ou clandestinidades de suas afirmações como povo.

Num confronto com a cultura hegemônica católica, as religiões de matrizes africanas constituem-se como periféricas e socialmente marginais, com inúmeras dificuldades por parte da sociedade em respeitá-las.

Devido a uma história de perseguições, violência e discriminação, aos terreiros restou fixarem-se em regiões periféricas ou regiões de baixa renda, fora dos grandes centros urbanos e predominantemente escondidos.

Ao mesmo tempo que as casas de matrizes africanas são os locais dos cultos, são também um símbolo de resistência. É lenta a conquista por respeito.

O direito à liberdade religiosa é essencial à formação subjetiva dos que partilham de crenças e rituais de natureza religiosa. A violação desse direito ou a criação de obstáculos a seu exercício constituem grave e indevida intervenção no mais profundo nível da personalidade. ${ }^{39}$

\footnotetext{
${ }^{39}<$ http://www.jur.puc-rio.br/depto/wp-content/uploads/2013/08/Cartilha-paraLegaliza\%C3\%A7\%C3\%A3o-de-Casas-Religiosas-de-Matriz-Africana.pdf $>$ Acesso em 17 de out. 2017
} 
Desse modo, é imperioso e urgente a organização dos templos religiosos. Através da regulamentação e legalização das casas de santo, pouco a pouco, passo a passo, o que se pretende, acima de tudo, é oferecer novos meios de enfrentar o racismo enraizado em nossa sociedade.

A Constituição Federal dispõe que "é inviolável a liberdade de consciência e de crença, sendo assegurado o livre exercício dos cultos religiosos e garantida, na forma da lei a proteção aos locais de culto e suas liturgias" (artigo 50, VI) e que "ninguém será privado de direitos por motivo de crença religiosa ou de convicção filosófica ou política, salvo se as invocar para eximir-se de obrigação legal a todos imposta e recusar-se a cumprir prestação alternativa, fixada em lei” (artigo 5, VIII).

Assim, não se pode interpretar a liberdade de crença apenas como direito de acreditar em alguma crença, mas sim, como o direito de externalizar uma crença. Ademais, a liberdade de culto representa também uma forma de manifestar a prática de atos próprios de cada religião.

Por certo, os direitos à liberdade religiosa devem ser interpretados sempre de forma ampla conjuntamente com os princípios constitucionais principalmente o da dignidade humana.

Logo, o direito fundamental à liberdade religiosa nada mais é que a expressão da dignidade da pessoa, sem qualquer juízo de valor sobre seu conteúdo.

Não é possível compreender, a partir de todas essas premissas expostas, como se pode ter casas religiosas legalizadas e respeitadas pela sociedade e outras não.

Novamente, o comportamento dos indivíduos numa sociedade reflete os parâmetros de aceite daquela sociedade. A discriminação contra religiões de matrizes africanas deve ser considerada como racismo acima de tudo.

Por isso, se faz tão importante a luta pela legalização de todas as casas de religião de matrizes africanas. Legalização não como um fim em si mesmo, mas como um dos caminhos possíveis da luta por respeito. Vivemos num país livre e democrático cujo direitos à liberdade de crença e 
culto em tese são garantidos pela nossa constituição. Infelizmente, não é o que se percebe na prática.

\subsection{Sentir na pele p $^{40}$}

Historicamente, as religiões de matriz africana têm sofrido constantes ataques racistas de todos os setores da sociedade brasileira. Nos últimos anos os (as) adeptos (as) dessas religiões passaram a sofrer uma maior e dura perseguição contra sua escolha religiosa tendo que testemunhar diversos casos de violência entre eles e presenciar a destruição de seus terreiros.

Por mais que seja assegurado no nosso ordenamento através de diversas normas e dispositivos legais, a liberdade religiosa e de crença na prática não é respeitada.

Os povos de terreiros vêm, aos poucos, sofrendo uma violência que, por mais que seja noticiada, diga-se de passagem, de uma forma muito mais leviana e sem o devido destaque, é silenciosa e dura. Durante séculos, as tentativas de apagamento da cultura afro-brasileira e do não reconhecimento da existência dessas religiões, primeiramente, como práticas religiosas, só contribuíram para um cenário de grandes perseguições.

A falta de informação e disseminação dos saberes religiosos dessas religiões no Brasil faz com que a imagem que essas religiões têm perante uma sociedade, de maioria católica, seja completamente distorcida, sendo veiculadas imagens e associações negativas às suas práticas.

A mídia ao invés de ajudar a informar e tentar desconstruir a imagem negativa criada sobre essas religiões, consequência de uma história de marginalidade e perseguição racistas, alimenta o ódio ao veicular propagandas negativas contra essas religiões seja veiculando através de

${ }^{40}$ Levantamento elaborado por Malu Stanchi, Abyian de Oyá do Ilê Àse Omiojúàró e graduanda em Direito pelo PUC-Rio. Rio de Janeiro, set. 2017. 
canais de televisão aberta ou pela internet. $\mathrm{E}$, mais triste ainda, é que não existe nenhum tipo de controle sobre esse conteúdo, ou melhor dizendo, esse tipo de conteúdo não sofre qualquer tipo de controle.

A dor, o sofrimento, o sangue derramado por parcela da população não atinge aqueles que detêm o poder para tentar mudar essa realidade de ódio. A dor do negro é invisível aos olhos do branco.

Os (as) adeptos (as) das religiões de matrizes africanas no Brasil não são exclusivamente negros (as), contendo muitos brancos adeptos, mas o que não se pode ignorar é que essas religiões representam formas de vida e cosmovisões negras.

Para complexificar o cenário, temos significativos grupos políticos que se elegem graças a seus discursos de intolerância e muitas vezes de ódio contra as minorias. $\mathrm{O}$ avanço da bancada evangélica na política brasileira acende a preocupação dos representantes das religiões de matrizes africanas acerca de um possível aumento nos discursos de ódio. A bancada neopentecostal é radicalmente contra seus cultos e crenças e promove discursos de intolerância contra essas religiões. Por mais que nem todo evangélico concorde e compactue com esses ideais, é flagrante o fato de que boa parte dos discursos de ódio contra as religiões de matriz africana no Brasil vêm dessa parcela religiosa (neopentecostal).

Não é muito difícil de encontrar exemplos práticos que representam essa realidade. Recentemente, a prefeitura do Rio de Janeiro ao promulgar um decreto municipal que institui o programa Rio Ainda Mais Fácil, que, em tese, regulamenta a realização de eventos na cidade obrigando a solicitação prévia para eventos religiosos, restringiu de forma absurda e autoritária as manifestações religiosas e culturais afro-brasileiras no Rio de Janeiro. Afinal, de acordo com esse decreto, qualquer tipo de prática religiosa vai ter que passar pelo crivo exclusivo de um governo assumidamente evangélico.

A intolerância religiosa contra as religiões de matrizes africanas é, na verdade, uma forma de racismo religioso. A supremacia branca vem 
perpetuando ao longo da nossa história o genocídio da população negra através de práticas que consistem na inferioridade, desvalorização e extermínio da identidade, cultura, dos corpos e dos símbolos africanos.

Graças a essa concepção de menosprezo do negro, as práticas de violência contra essas religiões vêm crescendo assustadoramente. Terreiros destruídos por completo, filhos de santos perseguidos, agredidos e até assassinados por recusa de destruir seus símbolos religiosos estão se tornando cada vez mais frequentes.

Nesse panorama de violência explicitado, numa breve pesquisa por veículos de notícias é possível encontrar apenas nesse ano inúmeros casos de agressão a casas de religiões de matrizes africanas no Rio de Janeiro.

Num breve dossiê que, a seguir se demonstrará, é possível perceber um padrão nos casos de ataques no Rio de Janeiro. As agressões sempre são realizadas de forma anônima, na maioria dos casos com desconfiança pelos vizinhos aos centros religiosos, com a justificativa de que as religiões de matrizes africanas são demonizadas, o que não seria permitido no "reino de Deus".

\section{a) Terreiro Ilê Axé Obá Inã - 29.7.2017}

O terreiro Ilê Axé Obá Inã, na Penha, Zona Norte do Rio de Janeiro, há pelo menos um ano e meio vem sofrendo diversos ataques causando buracos nas telhas de seu centro manifestados através de pedras portuguesas lançadas contra o centro. Além das pedras, muitas vezes foram jogados ovos e legumes podres.

Como retrata a reportagem, por mais que o babalorixá Márcio de Barú tenha tentado através do diálogo reverter a situação, só neste ano já são dois registros de ocorrência na $22^{\mathrm{a}} \mathrm{DP}$ da Penha por crime de intolerância religiosa.

\footnotetext{
${ }^{41}<$ https://extra.globo.com/casos-de-policia/um-rio-de-odio-terreiro-de-candomble-atacado-compedras-ovos-legumes-podres-21645654.html> Acesso em 29 de out. 2017
} 
Mesmo com as ocorrências, de acordo com o babalorixá, sempre que há festividades na casa, as tentativas de agressões continuam. Na última ocorrência registrada, a pedra portuguesa tacada contra a casa quase atingiu o rosto de um filho de santo.

\section{b) Terreiro Ilê Asé Togun Jobi - 6.9.2017}

O centro foi encontrado por seus frequentadores completamente destruído. Todas as imagens, objetos religiosos, instrumentos, artigos e móveis que estavam no centro foram completamente destruídos.

Esse caso foi registrado como o sétimo terreiro depredado em Nova Iguaçu nos últimos meses.

\section{c) Centro Espírita Unidos Pela Fé - 2.9.2017 $7^{43}$}

O terreiro localizado em Nova Iguaçu teve suas portas arrombadas, todos os objetos religiosos e as louças foram quebrados, além de terem sido roubados imagens e ataques do centro.

\section{d) Terreiro Humkpane Gu Waruleji - 2.9.2017 44}

Na mesma região, a casa Humkpane Gu Waruleji teve seus pertences roubados. Cinco assentamentos de orixás e roupas de santo desapareceram da casa.

\section{e) Oitavo terreiro em Nova Iguaçu é depredado - 26.9.2017}

No dia 5.9.2017, um terreiro localizado no bairro Parque Flora, em Nova Iguaçu, foi invadido por traficantes que depredaram a casa inteira.

\footnotetext{
${ }^{42}<\underline{\text { http://odia.ig.com.br/rio-de-janeiro/2017-09-08/denuncias-de-que-traficantes-teriam-atacado- }}$ terreiros-sao-investigadas.html> Acesso em 29 de out. 2017

$43<$ http://odia.ig.com.br/rio-de-janeiro/2017-09-02/em-uma-semana-seis-ataques-a-casas-deumbanda-e-candomble-em-nova-iguacu.html> Acesso em 29 de out. 2017

$\overline{44}<$ http://odia.ig.com.br/rio-de-janeiro/2017-09-02/em-uma-semana-seis-ataques-a-casas-deumbanda-e-candomble-em-nova-iguacu.html > Acesso em 29 de out. 2017

${ }^{45}<$ https://www.geledes.org.br/me-senti-sob-chicote-numa-senzala-relata-mae-de-santo/> Acesso em 29 de out. 2017
} 
Toda a ação foi filmada e postada nas redes sociais, nestes vídeos é possível ver que a mãe de santo responsável pelo terreiro é obrigada a quebrar os símbolos e objetos religiosos sob xingamentos de "feiticeira" e "bruxa".

Não satisfeitos em deixarem o terreiro reduzido a pó, os traficantes obrigaram um dos filhos de santo a quebrarem as guias, colares sagrados para a religião.

\section{f) Dona Maria da Conceição leva pedrada - 20.8.2017}

Ao sair de casa para ir ao mercado, Dona Maria da Conceição foi agredida a pedradas em Nova Iguaçu. Infelizmente, ela foi vítima de intolerância religiosa por parte de sua própria vizinha que não aceita a sua religião.

Como retrata a reportagem, segundo sua filha, Dona Maria era constantemente ofendida pelos vizinhos.

Ela teve ferimentos no rosto, na boca e no braço precisando ser levada ao Hospital Geral de Nova Iguaçu. O caso foi registrado na $58^{\circ} \mathrm{DP}$ de Nova Iguaçu como lesão corporal e injúria e não como intolerância religiosa.

\section{g) Casa do Mago - 16.8.2017}

Em menos de um mês, a casa espírita localizada no Humaitá, foi atacada três vezes. Na última tentativa, os criminosos incendiaram o portão da casa na madrugada parecido com o segundo ataque, no qual foi jogado um artefato explosivo dentro da casa.

Durante toda a sua trajetória, a Casa do Mago já sofreu inúmeras tentativas de ataques que podem ser considerados exclusivamente ataques de intolerância religiosa.

\footnotetext{
$46<$ http://odia.ig.com.br/rio-de-janeiro/2017-08-20/idosa-e-agredida-por-intolerancia-religiosaem-nova-iguacu.html > Acesso em 29 de out. 2017

${ }^{47}<$ http://odia.ig.com.br/rio-de-janeiro/2017-08-16/casa-do-mago-e-atacada-pela-terceira-vez-emmenos-de-um-mes.html> Acesso em 29 de out. 2017
} 
Estes casos representam uma parcela dos casos de intolerância no estado do Rio de Janeiro. Muitas vezes o medo de denunciar faz com que muitos representantes de terreiros se esquivem se tornando cada vez mais difícil chegar a um número exato de casos de intolerância. A realidade é que a quantidade de casos de violência contra centros religiosos de matrizes africana é muito maior do que os casos devidamente registrados.

Essa triste realidade parece não ter prazo para acabar, muito pelo contrário, com o que estamos vendo ao longo desse ano de 2017, os discursos de ódio têm aumentado, aumentando, assim, o medo e os casos de violência no Rio.

\section{3 “Chuta que é macumba!": a repressão disfarçada pelas denúncias}

O racismo e a intolerância religiosa contra as religiões de matrizes africanas são históricos, sistemáticos e estruturais ${ }^{48}$. Por todo o já exposto neste trabalho, não restam dúvidas de que toda perseguição religiosa contra essas religiões tem como pano de fundo o preconceito racial.

Historicamente, essas religiões têm na sua origem a resistência dos escravos em todo o período de escravidão no Brasil, seja no império quanto no período colonial. O que se vê é uma crescente incidência de um racismo religioso.

Importante frisar que o racismo na sociedade brasileira é uma ferramenta que estrutura a sociedade para a manutenção dos privilégios de uma minoria branca que detém o poder ${ }^{49}$.

Muitas vezes, a opressão branca se vê na utilização de religiões tidas como porta vozes da verdade para demonizar as divindades cultuadas nas

\footnotetext{
${ }^{48}$ Levantamento elaborado por Malu Stanchi, Abyian de Oyá do Ilê Àse Omiojúàró e graduanda em Direito pelo PUC-Rio. Rio de Janeiro, set. 2017.

$49<$ https://www.geledes.org.br/racismo-religioso-e-o-retrato-da-intolerancia-no-brasil/> Acesso em 29 de out. 2017
} 
religiões de matrizes africanas, acirrando, dessa forma, a relação violenta entre brancos e negros dentro de uma sociedade completamente racista.

Ao se analisar de forma profunda a discussão, não se pode negar que por trás de toda essa intolerância religiosa se tem o racismo velado e a tentativa de anulação de uma cultura inteira de ancestralidade africana.

Quando discutimos intolerância religiosa não podemos analisar o assunto apenas no âmbito da religião. Por ser uma sociedade construída em cima de pilares cristãos e brancos, desde que o Brasil se entende por organização social o negro sempre foi marginalizado, assim como tudo que vem dele.

Antes mesmo de tentar entender ou saber sobre os ensinos religiosos das religiões de matrizes africanas, pelo simples fato de vir do negro, um povo que sempre foi visto como sujo, traiçoeiro, feiticeiro, perigoso, suas religiões já eram rechaçadas.

Através do passar dos anos, essa concepção só se perpetuou e se tornou naturalizada em nossos cotidianos. Deste modo, não se pode dizer que a crescente perseguição religiosa se dá apenas contra a religião, mas sim contra uma religião que vem de um povo que sempre foi considerado marginalizado.

Não se pode fechar os olhos para um debate mais aprofundado, a partir da falta de apoio público e principalmente político, os casos de racismo religioso têm crescido cada vez mais e de forma assustadora. Até quando vamos fechar os olhos para essa realidade?

Aos adeptos (as) dessas religiões não negros, basta se despir do branco e de suas guias que passam a ser apenas mais um indivíduo numa sociedade racista, mas e para os negros? Eles não podem se despir da própria pele ${ }^{50}$.

\footnotetext{
${ }^{50}<$ https://olhardeumcipo.blogspot.com.br/2017/10/e-os-brancos-do-candomble.html?m=1> Acesso em 29 de out. 2017
} 
Acima de tudo, a perseguição religiosa se baseia na perseguição pela cor. No cenário atual, se faz imperioso a conscientização e o debate acerca do assunto.

Enquanto as estruturas de poder ignorarem esse problema, enquanto a nossa sociedade não conseguir enxergar o seu poder de destruição por causa de seus pilares primordiais de segregação racial, terreiros continuaram a serem destruídos, filhos e filhas de santo sofrerão violência dos mais variados tipos, as perseguições continuarão e mais sangue será derramado.

O primeiro passo para que uma população possa evoluir como um todo é o reconhecimento de que ela própria é segregacionista, racista, classista e acima de tudo intolerante a toda e qualquer diversidade não enquadrada no seu padrão branco, masculino, cristão e heteronormativo. 


\section{CAPÍTULO IV - ENTRE ESTADO E RELIGIÃO}

\subsection{O poder simbólico das leis}

A partir de todo o debate aqui constituído, é imperiosa a análise dos direitos de liberdade de crença e culto na nossa Constituição e a relação entre Estado e Religião.

Os maiores debates travados acerca desse conteúdo giram em torno da insatisfação acerca da interpretação e da aplicação desses direitos garantidos constitucionalmente.

Ao analisar o contexto constitucional brasileiro, o legislador originário não oferece uma orientação segura a respeito do alcance do direito à liberdade religiosa, ou sua efetiva aplicação, designando a livre interpretação para os casos concretos e abrindo margem para as convicções pessoais.

Nota-se que, em geral, a análise do tema é nitidamente formalista, limitando-se à apresentação de uma ideia ou um conceito genérico seguido de uma breve dissertação que ressalta a importância do direito em questão. ${ }^{51}$

Ao lado desse problema mais genérico, relacionado à interpretação constitucional, há também aspectos específicos, relacionados à interpretação da liberdade religiosa, comprometendo assim uma compreensão adequada e uma aplicação correta deste direito fundamental. Algumas peculiaridades em torno do próprio fenômeno religioso, juntamente com a consideração dos princípios constitucionais que se relacionam com a liberdade religiosa devem ser analisados quando em conflito no caso específico.

A proteção constitucional à liberdade religiosa, portanto, não se refere à tutela a uma corrente de ideias ou de pensamento, mas à compreensão de um direito mais

${ }^{51}$ LEITE, Fabio Carvalho. Estado e Religião. A liberdade Religiosa no Brasil. Curitiba: Juruá Editora., 2014, p. 301. 
amplo de liberdade de consciência, que assegura a autodeterminação existencial e ética dos indivíduos, a defesa do seu âmbito de racionalidade e de consciência, e que se desdobra em diversos campos, como o filosófico, o ideológico e o religioso. $^{52}$

Entretanto, por mais que seja assegurado o princípio da laicidade estatal, a própria Constituição traz em si uma herança histórica constitucional brasileira baseada em princípios católicos, uma vez que em seu preâmbulo há a menção expressa a Deus.

\begin{abstract}
Nós, representantes do povo brasileiro, reunidos em Assembléia Nacional Constituinte para instituir um Estado Democrático, destinado a assegurar o exercício dos direitos sociais e individuais, a liberdade, a segurança, o bem-estar, o desenvolvimento, a igualdade e a justiça como valores supremos de uma sociedade fraterna, pluralista e sem preconceitos, fundada na harmonia social e comprometida, na ordem interna e internacional, com a solução pacífica das

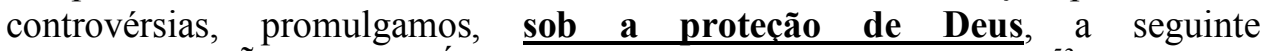
CONSTITUIÇÃO DA REPÚBLICA FEDERATIVA DO BRASIL ${ }^{, 53}$.
\end{abstract}

A princípio o preâmbulo não integra a Constituição, mas sim a precede. Por mais que, juridicamente, o preâmbulo não estabeleça normas constituintes, essa homenagem explícita representa sim uma manifestação de que a nossa sociedade é majoritariamente cristã ou, podemos dizer, católica. Como dito, mesmo que o preâmbulo não estipule normas a serem seguidas, ele demonstra uma herança religiosa carregada em nossa sociedade há séculos, escancarando, assim, que, por mais que a Constituição estabeleça que o Estado seja laico, não é assim que os próprios legisladores se comportam.

Conforme já destacado anteriormente nesse trabalho, as liberdades de culto e crença estão asseguradas no artigo $5^{\circ}$ da Constituição Federal sendo invioláveis e direitos assegurados à dignidade da pessoa humana.

A partir do estipulado no texto constitucional, a liberdade de culto pode ser considerada como a exteriorização da liberdade de crença e, esta

\footnotetext{
${ }^{52}$ LEITE, Fabio Carvalho. Op. cit., p. 308.

$53<$ http://www.planalto.gov.br/ccivil_03/constituicao/constituicaocompilado.htm> Acesso em 2 de nov. 2017
} 
última por ser uma manifestação individual de cada cidadão em desejar ou não professar alguma religião.

\begin{abstract}
Desse modo, deve-se assumir que a liberdade de crença é o direito de exprimir uma crença e não o de ter uma crença (condição necessária, mas não suficiente à caraterização deste direito fundamental). Reconhece-se que o conteúdo deste direito compreende contornos mais amplos do que o de simplesmente pode-se afirmar possuir uma crença, mas é este o seu núcleo de proteção. É dizer: é claro que a plena realização do direito à liberdade de crença depende não apenas do direito de exprimir a crença, mas de uma autodeterminação existencial a partir dela. ${ }^{54}$
\end{abstract}

Neste passo, tanto a liberdade de crença quanto a liberdade de culto estão no mesmo patamar constitucional, devendo a proteção de ambas ser assegurada e tutela pela Constituição de forma igualitária.

Assim, ao analisar o debate acerca dos direitos de manifestação religiosa, a Constituição, em seu artigo 19, I, assegura o princípio da laicidade ao vedar à União, aos Estados, ao Distrito Federal e aos Municípios estabelecer cultos religiosos.

Estabelecer cultos religiosos ou igrejas, subvencioná-los, embaraçar-lhes o funcionamento ou manter com eles ou seus representantes relações de dependência ou aliança, ressalvada, na forma da lei, a colaboração de interesse público; recusar fé aos documentos públicos; criar distinções entre brasileiros ou preferências entre si. ${ }^{55}$

O conceito de Estado laico está diretamente ligado à ideia do respeito a todas as religiões, indistintamente, observando sempre 0 princípio da isonomia. A partir dessa concepção está a preocupação de se evitar que em qualquer âmbito do poder ou qualquer ente federativo a existência de um tratamento diferenciado a certo grupo social em razão de sua religião. O que, convenhamos, não é o que estamos presenciando no atual governo da Prefeitura do Rio de Janeiro.

Além disso, deve se atentar ao fato que de que o artigo 19 permite a formação de alianças entre o Estado e religiões apenas quando há interesse

\footnotetext{
${ }^{54}$ LEITE, Fabio Carvalho. Op. cit., p. 313.

${ }^{55}<$ http://www.planalto.gov.br/ccivil_03/constituicao/constituicaocompilado.htm $>$ Acesso em 2 de nov. 2017
} 
público e na forma da lei. Essa brecha legislativa causa uma certa insegurança a partir do momento que não se estipula ao certo o que seria interesse público deixando a mercê de interpretação, o que muitas vezes é feito em favorecimento das tradicionais religiões.

Por mais assegurado que sejam esses direitos, paradoxalmente, é possível encontrar em locais públicos símbolos e monumentos religiosos de apenas um segmento da comunidade religiosa brasileira. Inúmeras são as salas de audiências públicas, gabinetes de políticos e o próprio Congresso Nacional, que possuem um crucifixo pendurado acima de todos nas paredes fazendo alusão à proteção de Jesus.

Mas afinal, o Estado não é laico? Por que é aceitável se ter um símbolo religioso de uma religião exposto em locais públicos enquanto outras inúmeras religiões, como as de matriz africana, ainda lutam por respeito e aceitação de seus símbolos religiosos?

Não há dúvidas que isso ilustra bem o cenário de tratamento desigual desse país. Enquanto a sociedade não entender que embora tenhamos bases históricas religiosas que ajudaram a construir muitas das concepções sociais de hoje, são múltiplas e devem ser protegidas as diversas formas de exercício religioso, bem como a possibilidade de não se vincular ou crer em nenhuma religião. Enquanto for aceito pela sociedade a ideia de que, independentemente da quantidade de religiões existentes no Brasil, há apenas uma que é a "verdade absoluta" e indiscutível, a discriminação disfarçada, a limitação de direitos e os discursos de ódio perdurarão por muito tempo.

\subsection{Ensino Confessional}

Ainda sobre esse debate acerca da laicidade do estado, é imprescindível destacar o julgamento recente prolatado pelo Supremo Tribunal Federal acerca da possibilidade do ensino confessional nas escolas públicas, no julgamento da Ação Direta de Inconstitucionalidade n ${ }^{\circ} 4439$. 
A Constituição Federal consagra, como já visto, o princípio da laicidade do Estado, em seu artigo 19, I, bem como a possibilidade do ensino religioso nas escolas públicas de ensino fundamental de maneira facultativa apenas (artigo $210, \S 1^{\circ}$ ).

Dessa forma, a Procuradoria Geral da República através de ação direta de inconstitucionalidade pleiteia a interpretação da norma constitucional pela Corte Suprema para que o ensino religioso em escolas públicas fosse somente de natureza não confessional.

Para a Procuradoria a única forma possível de unir o caráter laico do Estado brasileiro com o ensino religioso nas escolas públicas seria através da adoção de um modelo não confessional, isto é, em que o conteúdo da disciplina consistisse apenas na exposição das doutrinas, práticas, da história e de dimensões sociais das diferentes religiões sem qualquer tomada de partido por parte dos professores.

Nesse sentido, a própria Lei de Diretrizes e Bases da Educação Nacional $n^{\circ}$ 9.394/96 estabelece em seu artigo 33 que "o ensino religioso, de matrícula facultativa, é parte integrante da formação básica do cidadão e constitui disciplina de horários normais das escolas públicas de ensino fundamental, assegurado o respeito à diversidade cultural religiosa do Brasil vedada quaisquer formas de proselitismo" $"$.

Entretanto, como é possível vedar qualquer forma de proselitismo com o ensino confessional? A própria lei reforça o modelo não confessional, estabelecendo a premissa da natureza obrigatoriamente não confessional do ensino religioso.

Na prática, muitas vezes, os ambientes escolares são hoje um espaço de doutrinação religiosa, pois, por vezes, os próprios professores representantes de igrejas garantem esse tipo de ideologia.

A laicidade estatal além de salvaguardar as diversas religiões da influência do Estado, também protege o próprio Estado de influências provenientes de ensinos religiosos.

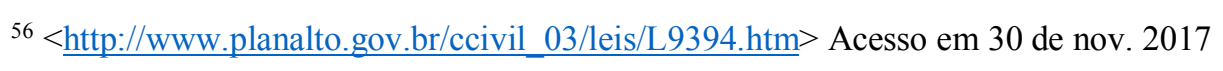


Cabe destacar que a laicidade nada tem parecido com o ateísmo, uma vez que, este último, na sua afirmação da negativa da existência de Deus não deixa de ser uma posição religiosa.

Assim, a laicidade impõe ao Estado a responsabilidade de se manter neutro em relação às diferentes religiões presentes no cenário brasileiro, sendo vedado o favorecimento para qualquer crença. A laicidade, acima de tudo, representa a maior garantia institucional da liberdade religiosa individual, além de garantir o tratamento igual a todos os indivíduos de uma mesma sociedade com diversos posicionamentos religiosos. ${ }^{57}$

Infelizmente, de maneira surpreendente o Supremo Tribunal Federal acabou optando pelo entendimento da possibilidade do ensino confessional nas escolas públicas.

O Supremo Tribunal Federal, hoje, integralmente branco, não poderia ter uma visão mais expansiva acerca do tema sobre as suas consequências na prática, principalmente para aquelas crianças que são adeptas de religiões de matrizes africanas, se não o resultado desse julgamento.

De fato, se o professor da disciplina não é vinculado a uma religião específica, tampouco subordinado a ela; se o conteúdo da matéria atravessa todas as religiões e está mais voltado pra o fenômeno religioso como gênero do que para as religiões como espécies; se a aula, por conseguinte, não terá caráter catequético, onde se mistura uma doutrina religiosa, então nada há que impeça o professor efetivamente integre uma carreira de magistério, que se submeta a um concurso público promovido pelo Estado e que seja remunerado por este. ${ }^{58}$

Assim, pois, deveria ser o pensamento empregado na prática. $\mathrm{O}$ fato de se ter ensino religioso nas escolas públicas não é o que geraria o medo em certos setores religiosos da sociedade, se ele ao menos fosse de forma imparcial e demonstrasse a existência de todas as religiões e seus ensinamentos, mas sim a possibilidade de um professor pregar a sua própria religião.

\footnotetext{
${ }^{57}$ LEITE, Fabio Carvalho. Op. cit., p. 366.

${ }^{58}$ Ibid. p. 353.
} 
Se durante as aulas houvesse realmente o ensino de todas as religiões e suas práticas, isso incluindo as religiões de matrizes africanas que na maioria dos casos não são retratadas sequer como religiões, muitos casos de intolerância e de discurso de ódio presentes nas escolas seriam evitados.

Como afirmou Nelson Mandela:

Ninguém nasce odiando outra pessoa pela cor de sua pela, por sua origem ou ainda por sua religião. Para odiar as pessoas precisam aprender, e se elas aprendem a odiar, podem ser ensinadas a amar, pois o amor chega mais naturalmente ao coração humano do que o seu oposto. ${ }^{59}$

Seguindo por esse pensamento, se nenhum indivíduo nasce odiando o próximo ele precisa aprender esse tipo de prática de alguma forma, seja dentro de casa, seja na rua. Com a possibilidade do ensino confessional nas escolas não se pode fechar os olhos à possibilidade de uma disseminação de discurso de ódio contra certas religiões.

Como real a possibilidade de pregação dentro de salas de aulas, os casos que já representam números que vêm chamando atenção de intolerância religiosa nas escolas contras as crianças adeptas às religiões de matrizes africanas só aumentarão.

Dessa forma, essa nova realidade só contribui para um ambiente em que as próprias crianças se sentirão constrangidas de participar de aulas de religião, na qual seu professor pode ser de uma religião oposta que abomina as práticas religiosas afro-brasileiras.

Mesmo sendo facultativo o ensino, inevitável será o constrangimento daquela criança praticante de alguma religião de matriz africana ao se negar participar de aulas de pura doutrinação religiosa oposta à sua crença que prega a demonização de suas práticas.

Como já pode se perceber através desse trabalho, muitos dos casos, se não todos, aqui retratados de intolerância religiosa são causados em nome de uma fé e de uma religião que prega sua superioridade demonizando as práticas das religiões de matrizes africanas. O crescimento

$59<$ https://www.pensador.com/frase/MzY0Nzkx/> Acesso em 30 de out. 2017 
de adeptos às religiões neopentecostais na população brasileira representa um grande alerta e insegurança para todos os que vestem o branco, desse modo será uma realidade muito próxima em veremos professores adeptos dessas religiões pregando discursos de ódio e incitando a perseguição às religiões afro-brasileiras por serem demonizadas.

O medo de expressar sua religião dentro do ambiente escolar, com o tempo, de forma inevitável, só crescerá. O medo de retaliações por parte dos professores se tornará cada vez mais presente no cotidiano das crianças de religiões afro-brasileiras.

\subsection{Abate de animais em rituais religiosos}

Ao tratar sobre a controvérsia de uma das práticas religiosas afrobrasileiras tradicional e muito polêmica devido ao preconceito e à desinformação que revestem o debate, o abate de animais para rituais religiosos tem sido o foco central entre a disputa dos defensores de animais e os representantes dessas religiões.

Em 1999, no Rio Grande do Sul, o deputado Manoel Maria (PTB) apresentou a última de inúmeras alterações ao projeto do Código de Proteção aos Animais, através do Projeto de Lei 230/99. Assim, em 21 de maio de 2003, o projeto se transformou na Lei 11.915/03, que dispõe em seu artigo $2^{\circ}$, incisos I e IV:

\footnotetext{
Art. $2^{\circ}$. É vedado ofender ou agredir fisicamente os animais, sujeitando-os a qualquer tipo de experiência capaz de causar sofrimento ou dano, bem como os que criem condições inaceitáveis de existência.

I - ofender ou agredir fisicamente os animais, sujeitando-os a qualquer tipo de experiência capaz de causar sofrimento ou dano, bem como as que criem condições inaceitáveis de existência;

$[\ldots]$

IV - não dar morte rápida e indolor a todo animal cujo extermínio seja necessário para consumo. ${ }^{60}$
}

${ }^{60}<$ http://www.al.rs.gov.br/legiscomp/arquivo.asp?Rotulo=Lei\%20n\%BA\%2011915\&idNorma=3 2\&tipo=pdf> Acesso em 31 de out. 2017 
A partir dessa redação, a discussão envolvendo as práticas religiosas de matriz africana teve seu início, representando uma grave ameaça ao possibilitar a proibição legal aos rituais religiosos inviabilizando suas práticas.

Visando uma solução para o embate, o então deputado Édson Portilho apresentou o Projeto de Lei $n^{0}$ 282/03 que acrescentava um parágrafo no artigo $2^{\circ}$ à Lei $11.915 / 03$, buscando garantir expressamente em lei as práticas de cunho religioso acerca do abate.

Desse modo, em 22 de julho de 2004, o então Governador do Rio Grande do Sul, Germano Rigotto, sancionou o Projeto de Lei proposto pelo deputado acarretando na Lei 12.131/04, restando o artigo $2^{\circ}$ da Lei 11.915/03 regulamentado pelo Decreto 43.252 de 22 de julho de 2004, que dispõe em seu artigo $2^{\circ}$ :

Art. $2^{\circ}$. Para o exercício de cultos religiosos, cuja liturgia provém de religiões de matriz africana, somente poderão ser utilizados animais destinados à alimentação humana, sem utilização de recursos de crueldade para sua morte ${ }^{61}$.

Com a mudança na Lei, grupos defensores dos animais procuraram o Ministério Público do Rio Grande do Sul para o ingresso com uma ação contra a emenda acrescentada ao Código de Proteção de Animais. Deste modo, em 17 de outubro de 2004, o então Procurador Geral de Justiça do Rio Grande do Sul, Roberto Bandeira Pereira, propôs Ação Direita de Inconstitucionalidade, cujo objetivo era a retirada do ordenamento jurídico do parágrafo único do artigo $2^{\circ}$ da Lei $n^{\circ} 11.915 / 03$, acrescentado pela Lei $\mathrm{n}^{\mathrm{o}} 12.131 / 04$, que passou a ter a seguinte redação "não se enquadra nessa vedação o livre exercício dos cultos e liturgias das religiões de matriz africana" $"$.

Essa ação tem como fundamento declarar a inconstitucionalidade por simples dois motivos (i) a Lei $n^{0} 12.131 / 04$ trata de matéria penal, cuja

\footnotetext{
${ }^{61}<$ http://www.al.rs.gov.br/legis/M010/M0100099.ASP?Hid Tipo=TEXTO\&Hid TodasNormas= $47826 \&$ hTexto $=\&$ Hid_IDNorma $=47826>$ Acesso em 31 de out. 2017

${ }^{62}<$ http://www.al.rs.gov.br/filerepository/repLegis/arquivos/12.131.pdf $>$ Acesso em 31 de out. 2017
} 
competência legislativa seria privativa apenas à União; (ii) o desrespeito ao princípio da isonomia previsto na Constituição Federal ao abrir exceção apenas aos cultos de matriz africana o que infringiria o princípio da laicidade estatal estipulado no artigo 19, I, da Constituição.

Esta ação continua sendo discutida até hoje no Supremo Tribunal Federal com a interposição de Recurso Extraordinário pelo Ministério Público do Rio Grande do Sul de número 494.601 que se encontra pendente de julgamento.

Apesar de todo o debate acerca do tema, repita-se, toda a discussão se resume ao fato de que as práticas religiosas afrobrasileiras ainda continuam incompreendidas. A falta de conhecimento por parte da sociedade faz com que se tenha uma imagem negativa acerca dos rituais religiosos dessas religiões.

Acima de tudo, as religiões de matrizes africanas são modos de vida baseados em valores herdados de sociedades tradicionais e históricas africanas que através de seus ensinamentos deixaram como legado suas visões de mundo.

Para essas sociedades tudo neste mundo é interligado. Animais, humanos, divindades, vegetais e minerais são entendidos com entidades animadas pelas forças vivas e vivificadoras ${ }^{63}$. Assim, o mundo é composto através de interligações entre os seres que neste plano vivem, sendo necessária a manutenção do equilíbrio dessa organização.

A energia vital presente nesse mundo e habitante de todos os seres existentes, sejam animados ou não, na concepção dessas religiões precisa ser mantida em equilíbrio para que o mundo possa seguir seu caminho entrelaçando as diferentes energias aqui presentes.

$\mathrm{Na}$ percepção das religiões de matriz africana, tudo se alimenta e se relaciona. A partir do momento que o ciclo natural do mundo através da coexistência de toda a matéria presente como ser regida pela mesma força

\footnotetext{
${ }^{63}<$ https://enugbarijo.wordpress.com/2017/05/11/argumentacao-da-comissao-de-preservacao-esalvaguarda-dos-terreiros-tombados-referente-ao-recurso-extraordinario-no-494-601-7210/> Acesso em 31 de out. 2017
} 
vital, a alimentação se faz essencial seja essa para a subsistência particular de cada indivíduo, seja dentro das concepções de seus cultos religiosos.

Para essas religiões milenares, dentro de seus terreiros não há ritual sem a devida alimentação que fomenta as relações, dentro de suas crenças, com as divindades, com a natureza e com os indivíduos entre si dentro de sua comunidade religiosa ou fora, uma vez que todos estão sempre convidados a participar das festas realizadas sendo adeptos (as) ou não.

É junto que se vive. A interligação de todos os indivíduos dentro do terreiro é mais do que necessária, é essencial. Todos os seres nesse mundo estão interligados entre si, assim como com a mãe natureza em todas as suas formas.

Nos rituais religiosos em que há a imolação animal, o princípio fundamental é que as divindades e a comunidade se alimentem e fortaleçam seu caráter articulado e dinâmico ${ }^{64}$.

Importante destacar que para essas religiões, as divindades cultuadas compõem a organização social do mesmo modo que qualquer indivíduo presente em seus rituais. Junto disso, através de uma hierarquia, os ancestrais recebem a alimentação primeiro que os demais, mas em comunhão com a comunidade.

Como gesto de comunhão, nada deve ser desperdiçado dentro dos terreiros. Às divindades não é oferecido apenas o alimento animal, mas sim tudo o que sua comunidade religiosa come, visto que tudo é compartilhado.

Dentro de suas hierarquias, para a imolação de um animal é necessária a comunicação com os orixás, isto é, se tem dentro de seus rituais diversos códigos a serem seguidos para que os rituais ocorram com as imolações.

Nessa perspectiva, os ensinamentos religiosos dessas religiões não permitem o sofrimento do animal que será abatido. Eles devem ser sempre bem tratados, reverenciados e festejados enquanto ainda vivos.

\footnotetext{
${ }^{64}<$ https://enugbarijo.wordpress.com/2017/05/11/argumentacao-da-comissao-de-preservacao-esalvaguarda-dos-terreiros-tombados-referente-ao-recurso-extraordinario-no-494-601-7210/> Acesso em $1^{\circ}$ de nov. 2017
} 
A crueldade não pode existir dentro dos terreiros, uma vez que os colocaria sob risco de perturbar as forças vitais que os rituais buscam equilibrar.

Deve se destacar também que o Decreto Federal n $n^{\circ} 6.040 / 07$, que institui a Política Nacional de Desenvolvimento Sustentável dos Povos e Comunidades Tradicionais, estabelece dentre seus princípios, a segurança alimentar como direito de todas as comunidades, conforme estipula seu artigo $1^{\circ}$, III.

A segurança alimentar e nutricional como direito dos povos e comunidades tradicionais ao acesso regular e permanente a alimentos de qualidade, em quantidade suficiente, sem comprometer o acesso a outras necessidades essenciais, tendo como base práticas alimentares promotoras de saúde, que respeitem a diversidade cultural e que sejam ambiental, cultural, econômica e socialmente sustentáveis ${ }^{65}$.

É importante frisar que o atual sistema de alimentação utilizado pelas sociedades hoje impõe uma mortandade desenfreada de todas as formas de vida que aqui ainda existem, animais ou não. Nesse cenário, conveniente se faz a perseguição às práticas de abate de animais das religiões de matrizes africanas.

Como já destacado, nos rituais religiosos a maior preocupação se faz em relação ao não sofrimento do animal buscando sempre um equilíbrio de energias dentro do terreiro como uma única forma de interação por si só.

A falta de informação aliada a uma perseguição histórica às práticas religiosas afro-brasileiras faz com que sejam disseminadas informações negativas e inverídicas de como os rituais se dão.

Não só a falta de informação como a falta de interesse por parte da sociedade em entender as práticas dessas religiões que sempre foram marginalizadas e atacadas acarreta num discurso de proibição de práticas que na sua essência mal nenhuma causam aos animais.

${ }^{65}<$ http://www.planalto.gov.br/ccivil 03/_ato2007-2010/2007/decreto/d6040.htm> Acesso em $1^{\text {o }}$ de nov. 2017 
A indiferença por aqueles que defendem a proibição das práticas ao significado que esse ritual possui para as suas religiões só reafirma o descaso da sociedade em relação ao sagrado na concepção das práticas afrobrasileiras.

Resta o questionamento aqui, por que deveria ser imprescindível a proibição da imolação de animais nos rituais de terreiros quando é socialmente aceito em outras práticas?

Embora as religiões de matriz africana gozem de garantias constitucionais como a liberdade de culto, cotidianamente têm de lutar contras novas situações de discriminação.

Enquanto continuarmos nos deparando com o cenário de uma sociedade branca, cujos cargos de poder se encontram majoritariamente concentrado nas mãos de brancos regidos, principalmente, por ideais católicos, as tentativas de cercear as práticas religiosas afro-brasileiras serão constantes.

Numa sociedade cega em relação à sua concepção racista e discriminatória, não as reconhecendo como estrutural e sistemática, não há como se exigir atitude diferente se não a tentativa de restringir práticas religiosas ainda não compreendidas.

Até quando seremos coniventes com essa perseguição? Até o momento em que todos os traços culturais e práticas religiosas sejam apagadas da nossa sociedade?

Por mais difícil que seja sobreviver a essa tentativa de massacre e extermínio das religiões de matrizes africanas no Brasil, como a nossa própria história já mostrou, a resistência sempre será forte.

\subsection{A federalização dos crimes de intolerância religiosa}

Nessa perspectiva, visando uma maior segurança, ou melhor, visando assegurar o mínimo possível para que a justiça pode ser realmente 
aplicada aos casos de perseguição religiosa, hoje se tem o debate acerca da federalização das investigações sobre os crimes de intolerância religiosa.

Cada vez mais crimes bárbaros se somam a tantas outras violências contra o povo de terreiro. Um novo debate sobre os últimos acontecimentos de perseguição religiosa em todo o país é necessário, mas principalmente o respeito à diversidade.

A partir disso, primeiro deve-se destacar que a liberdade de culto e religião é cláusula pétrea da nossa Constituição, sendo assim, deveria ser defendido em qualquer instância e circunstância o direito de todos de manterem suas identidades e raízes.

O Estado, em 1890, deixou de ser um Estado católico e passou a ser um Estado laico. Entretanto, o que vemos na prática é o oposto disso. $\mathrm{O}$ Estado é neutro no sentido de não professar nenhuma religião e o mesmo deveria ser aplicado nos casos de julgamento de perseguição religiosa.

Não posso deixar de destacar, mais uma vez, se o Estado é laico e não professa religião, não se pode ter nenhum símbolo religioso identificando qualquer local público, principalmente aqueles que representam as nossas esferas dos poderes legislativo, judiciário e executivo, porém não é o que se encontra. Em muitas das salas de reunião é possível ver um crucifixo pendurado.

Os casos crescentes de intolerância religiosa vêm travestidas de uma cultura de racismo, machismo, preconceito quanto às religiões de matriz africana. A diversidade cultural e religiosa é fundamental para a construção de uma nação e a sua não existência é o mesmo que consagrar o fim de uma sociedade igualitária.

Deste modo, a federalização dos crimes contra as casas e os adeptos(as) das religiões de matriz africana se mostra como uma nova forma de se enfrentar uma forte perseguição religiosa.

A possibilidade da federalização dos crimes contra os direitos humanos veio com a Emenda Constituição 45/04 que consiste basicamente no deslocamento de competência da Justiça Comum para a Justiça Federal, 
apenas nos casos em que ficar provado grave violação aos direitos humanos.

Assim, a federalização tem como objetivo assegurar uma maior proteção efetiva aos direitos humanos e ao cumprimento das obrigações do Brasil em relação à tratados internacionais. Este incidente pode ser suscitado apenas pelo Procurador Geral da República sendo uma medida de caráter excepcional pelo que ela representa. Conforme a Constituição Federal estipula:

Art. 109. Aos juízes federais compete processar e julgar:

(...)

V-A as causas relativas a direitos humanos a que se refere o $5^{\circ}$ deste artigo;

(...)

$5^{\circ}$ Nas hipóteses de grave violação de direitos humanos, o Procurador-Geral da República, com a finalidade de assegurar o cumprimento de obrigações decorrentes de tratados internacionais de direitos humanos dos quais o Brasil seja parte, poderá suscitar, perante o Superior Tribunal de Justiça, em qualquer fase do inquérito ou processo, incidente de deslocamento de competência para a Justiça Federal. ${ }^{66}$

Os inúmeros episódios de intolerância religiosa crescentes por todo o país representam grave violação dos direitos humanos às Religiões AfroBrasileiras, além dos crimes de racismo e genocídio, fato este que, por si só, já justifica a federalização das investigações em casos de perseguição religiosa às religiões de matrizes africanas.

Como a própria Declaração Universal dos Direitos Humanos determina em seu artigo 18, abaixo, todo indivíduo tem garantida como direito fundamental a liberdade religiosa, não podendo haver qualquer discriminação por sua escolha religiosa.

Artigo $18^{\circ}$

Todo ser humano tem direito à liberdade de pensamento, de consciência e de religião; este direito inclui a liberdade de mudar de religião ou crença e a liberdade de manifestar essa religião ou crença pelo ensino, pela prática, pelo culto em público ou em particular. ${ }^{67}$

${ }^{66}<$ http://www.planalto.gov.br/ccivil_03/constituicao/constituicao.htm> Acesso em 27 de out. 2017

$67<$ https://www.unicef.org/brazil/pt/resources_10133.htm> Acesso em 28 de out. 2017 
Diante desse contexto, a federalização dos crimes por intolerância religiosa em relação às religiões de matriz africana já deveria ter ocorrido faz tempo.

Por ser assegurada a possibilidade de federalização nos casos de grave violação a qualquer direito humano, não restam dúvidas, assim, acerca da violação aos direitos humanos nos casos de perseguição religiosa. Como visto, a própria Declaração de Direitos Humanos estipula que o direito à liberdade religiosa se encontra no rol dos direitos fundamentais intrínsecos a todos os indivíduos.

Entretanto, hoje, toda a comunidade de santo encontra-se nas mãos da Procuradora Geral, Deborah Duprat, de intervir nas investigações desses crimes cometidos por todo o país.

Por mais que existam formalidades a serem seguidas, a liberdade religiosa é um direito fundamental, sim, que deve ser respeitado em todos os setores da sociedade e o culto às religiões de matrizes africanas devem ser assegurados como qualquer outro tipo de manifestação religiosa. Nenhuma religião é superior ou mais certa que outra, todas são, dentro de suas particularidades, formas de expressar o sagrado. Então devemos garantir a expressão de todos os sagrados.

\subsection{Genocídio}

A necessidade da comunidade internacional de chegar à uma resposta para as inúmeras práticas de extermínio cultural e racial durante diversos períodos da história da humanidade fez com que a Organização das Nações Unidas (ONU) aprovasse em 11 de dezembro de 1946, a Resolução 96 que estabelece que:

O genocídio é a negação de existência de grupos humanos, como o homicídio é a negação do direito de viver dos seres humanos; tal negação do direito de existência choca a consciência da humanidade, resulta em grandes perdas para a 
humanidade na forma de contribuições culturais e outras representadas por esses grupos humanos. ${ }^{68}$

A imprescindibilidade da tipologia do genocídio e de sua criminalização veio a partir de uma noção que de todos os indivíduos devem ser além de fisicamente protegidos, ser culturalmente preservados buscando sempre evitar o extermínio de qualquer tipo de grupo. ${ }^{69}$

Nesse contexto, a partir de tudo já analisado nesse trabalho, enquanto a nossa sociedade for influenciada por normas degradantes de uma hegemonia branca, o racismo será um dos maiores responsáveis pelo genocídio do povo negro no Brasil.

Genocídio que aqui se trata se faz em ambos os aspectos, tanto físico como cultural. O Estado ao permitir e patrocinar atos de agressão, violência, violação dos corpos negros seja através do chocante número de negros mortos diariamente em nosso país, seja pela tentativa silenciosa de apagar aos poucos todo uma cultura negra da história, só contribui cada vez mais com essa realidade.

Com as inúmeras dificuldades impostas pelo Estado predominantemente controlado por brancos de se analisar a fundo através de dados a marginalização e o genocídio do povo negro faz com que seja quase que uma heresia a ideia do genocídio do negro.

Fique evidente desde já, genocídio não se limita a noção de extermínio. Ações que infrinjam a liberdade, a dignidade e a segurança de um grupo social é o suficiente para caracterizar o genocídio. ${ }^{70}$

No Brasil, para além da dimensão do extermínio e do superencarceramento, o genocídio do povo negro tem como seu alicerce os ideais branqueadores inerentes à nossa realidade. A tentativa constante de imposição de um comportamento branco a todos como padrão único a ser

\footnotetext{
${ }^{68}$ FLAUZINA, Ana Luiza Pinheiro. As Fronteiras Raciais do Genocídio. Revista de Direito da Universidade de Brasília, Brasília, v. 1, n. 1, jun. 2014, p. 121.

${ }^{69}$ Ibid. p. 121.

70 VARGAS, João Costa. A Diáspora Negra como Genocídio: Brasil, Estados Unidos ou uma geografia supranacional da morte e suas alternativas. Revista da ABPN, Goiânia, v. 1, n. 2, jul. 2010 , p. 36.
} 
seguido vem se mostrando como uma tentativa de anulação da cultura do povo negro, de suas formas de vida, de seus saberes, cosmovisões e tradições.

A supremacia branca e o racismo antinegros são genocidas. Complementando suas mais óbvias manifestações finais, a supremacia branca e o racismo antinegros trabalham igualmente com o silêncio, a inércia e a ignorância. Tanto a supremacia branca quanto o racismo antinegros acontecem por causa do que nós e os outros fazemos, assim como pelo que não fazemos. Consequentemente, o silêncio, a inércia e a ignorância são tão genocidas quanto os pensamentos e ações mais evidentes racistas. ${ }^{71}$

A crença na inferioridade do negro é permanentemente reinventada. O racismo está enraizado na essência do nosso comportamento social e institucional e seus modos de operação e consequências continuam não encontrando o enfrentamento público necessário para sua superação.

A apropriação da cultura do negro pelo branco é uma das marcas da tentativa de extermínio da cultura. Ao se tentar "embranquecer" a cultura do negro e sua identidade, o branco tenta eliminar, aos poucos, todo um povo e os traços culturais que este país carrega historicamente.

Por mais que se tente inúmeras vezes negar, este país é majoritariamente não branco, sua história foi construída sobre lágrimas, suor e muito sangue derramado pelo povo negro e indígena.

Essa tentativa descarada de anulação da identidade negra pela concepção de branquitude nada mais é que uma tentativa clara de genocídio desse povo.

O povo negro incomoda e é visto como uma ameaça permanente à hegemonia branca. Uma hegemonia que se sustenta e só faz sentido em um contexto de imensa desigualdade racial. Para que exista a "superioridade" tem que haver aquele considerado inferior.

Enquanto a brancura perdurar como padrão normativo de humanidade e respeito, permanecerá essa noção de que o que vem do branco é melhor, é o certo, é limpo, é puro, o moral, o lícito e o racional.

\footnotetext{
${ }^{71}$ Ibid. p. 56.
} 


\section{Conclusão - Cadê o respeito?}

Ao longo do trabalho foram discutidas algumas das formas através das quais o racismo se manifesta em nossa sociedade, principalmente no que se refere às religiões de matrizes africanas. O tema abordado, como já explicitado na introdução e demonstrado nos demais capítulos, possui notória importância, tendo em vista as frequentes tentativas de aniquilamento da cultura do povo negro.

Para o melhor entendimento acerca da constituição do racismo em nossa sociedade, foi necessário, a princípio, compreender historicamente a posição do negro em nossa sociedade, tanto no sentido cultural como no sentido de expressão de um povo como classe social. Nesse contexto, foi de suma importância entender que para se instaurar um debate acerca das formas do racismo e do genocídio do negro, é necessário, antes de tudo, verificar e analisar como a branquitude se impôs como padrão comportamental da nossa sociedade. Apenas no cenário em que se afirma a superioridade branca é que se poderá debater as consequências da discriminação ao negro de forma tão natural.

Ao negro, desde sempre, foi imposta a supressão de seus direitos e a supremacia do branco, restando apenas o papel de marginalizado. Foi retirado do povo negro, durante toda a história da nossa sociedade, sua maior força, sua voz.

O racismo não é apenas um problema do negro, é um problema de uma sociedade completamente racista e classista. Vemos claramente dentro da nossa realidade brasileira a herança da concepção da inferioridade do negro em relação ao branco.

Indiscutível é a presença em nosso comportamento da identidade branca como norma padrão. O silêncio, a omissão e a distorção do lugar do branco dentro de uma realidade de sociedade completamente desigual têm um papel fundamental na construção do ideal de condição humana. Esse 
racismo enraizado em nossa sociedade de forma mascarada faz com que seja aceito por toda a população a colocação no negro num lugar de inferioridade.

A ideologia de branqueamento presente em nosso comportamento social fez com que fosse necessária a reprodução do comportamento do branco em todos os setores, seja nos cargos de poder, nas instituições, seja nas relações sociais do dia-a-dia. Essa hegemonia da identidade branca faz com que o próprio negro seja impedido de formar sua identidade negra.

Entenda-se, de uma vez por todas, essa indiferença do branco à realidade de desigualdade de papéis não pode mais ser tolerada. Somos todos iguais independente da cor da pele.

Através dessa realidade de discriminação e segregação que promove uma condição de inferioridade do negro, as religiões de matrizes africanas vêm sendo alvo preferencial de discursos de ódio.

Por certo, os direitos à liberdade de culto e de crença por mais que garantidos constitucionalmente vêm sofrendo diversos ataques colocando em risco os direitos garantidos à expressão religiosa das religiões de matrizes africanas.

Destaca-se, novamente, o comportamento dos indivíduos de uma sociedade reflete os parâmetros de aceite daquela mesma sociedade. Sendo assim, a discriminação religiosa deve ser entendida como racismo acima de tudo.

Através de uma história de marginalidade e perseguições racistas, os discursos de ódio estão cada vez mais presentes em nossa sociedade, sendo esse comportamento, muitas vezes, aceito, se transformando numa concepção cada vez mais enraizada. A dor do negro é invisível ao olhar do branco.

Não muito difícil, chega-se à conclusão de que a intolerância religiosa não passa de um racismo religioso de forma mascarada. A identidade branca da nossa sociedade vem perpetuando ao longo da nossa história o genocídio da população negra. 
Essa opressão branca se utiliza de discursos de ódio para demonizar as divindades cultuadas nas religiões de matrizes africanas, reafirmando a superioridade branca até na forma de entendimento acerca do religioso, acirrando, cada vez mais, a relação entre brancos e negros.

Nesse panorama de violência explicitado, não há como se negar que por trás de toda essa perseguição religiosa está o racismo e a tentativa de aniquilamento de toda uma cultura.

Graças a essa concepção de superioridade branca como identidade, comportamento e até no sagrado, é que temos, hoje, infelizmente, a tentativa de proibição de uma das práticas religiosas mais tradicionais do mundo sagrado negro.

Como é possível em plena atualidade que o debate acerca da proibição ou não de uma prática religiosa não envolva de maneira não hierarquizada os adeptos dessas práticas? Até quando vamos justificar publicamente manifestações do sagrado de outras crenças sejam objeto de avaliações depreciativas e racistas?

Escandalosamente, é o que temos presenciado. A tentativa de exterminar a herança cultural e religiosa do negro se torna cada vez mais explícita. O simples fato de termos uma disputa judicial acerca de uma prática religiosa de religiões que historicamente foram perseguidas e por, muitas vezes, silenciadas, já diz por si só a triste e vergonhosa realidade de violência que se impõe às expressões culturais negras, mas não apenas. Por mais assegurada que seja a laicidade estatal, a tentativa de genocídio do povo negro se torna cada vez mais explícita.

A supremacia branca e o racismo, seja religioso ou não, são genocidas. As constantes tentativas de anulação da identidade negra através do branqueamento social é a mais clara tentativa de genocídio desse povo.

Verdade seja dita, quando há a necessidade de inferioridade do outro, resta explícita a ameaça que esse grupo representa. O povo negro incomoda e incomodará, está na hora da branquitude passar a se constituir por si mesma e não mais na negação e inviabilização do que toma como ameaça. 
Está mais do que na hora de mudanças. Em sociedades democráticas e plurais, a brancura como padrão tem que acabar e para isso é necessário que a sociedade passe a enxergar essa realidade de privilégios construídos em cima de práticas segregacionistas.

$\mathrm{O}$ reconhecimento de uma sociedade intolerante é o primeiro passo para a tentativa de mudança nesse cenário eterno de violência contra a cultura, a crença e os próprios corpos do negro.

Defender a nossa igual humanidade pressupõe assumir os efeitos políticos de efetivamente nos tratarmos como iguais, independentes da cor, ocupando os mesmos lugares de poder na nossa sociedade. Acima de tudo, afirmar a dignidade da pessoa humana igual a todos.

Não serão discursos de ódio que irão reprimir de vez as práticas religiosas de matrizes africanas. O negro resistiu a todas as formas de tentativa de genocídio de seu povo até hoje e continuará resistindo. A resistência negra não desaparecerá, pelo contrário, ela só se fortalecerá cada vez mais, visto que não há mais como fechar os olhos para a nossa discrepante realidade racial.

A cultura do negro resistirá! Assim, como suas crenças. Respeite o sagrado. Respeite as diferenças. Respeite a cor da pele. Respeite minha religião. RESPEITE, apenas RESPEITE. 
Eu não bato na sua porta!

Eu não canto no Metrô!

Eu não grito dentro do Ônibus!

Eu não te entrego panfleto!

Eu não insisto que você seja o que eu acredito!

Eu não invado o seu espaço!

Então...

NÃO INVADA O MEU TERREIRO! $!^{72}$

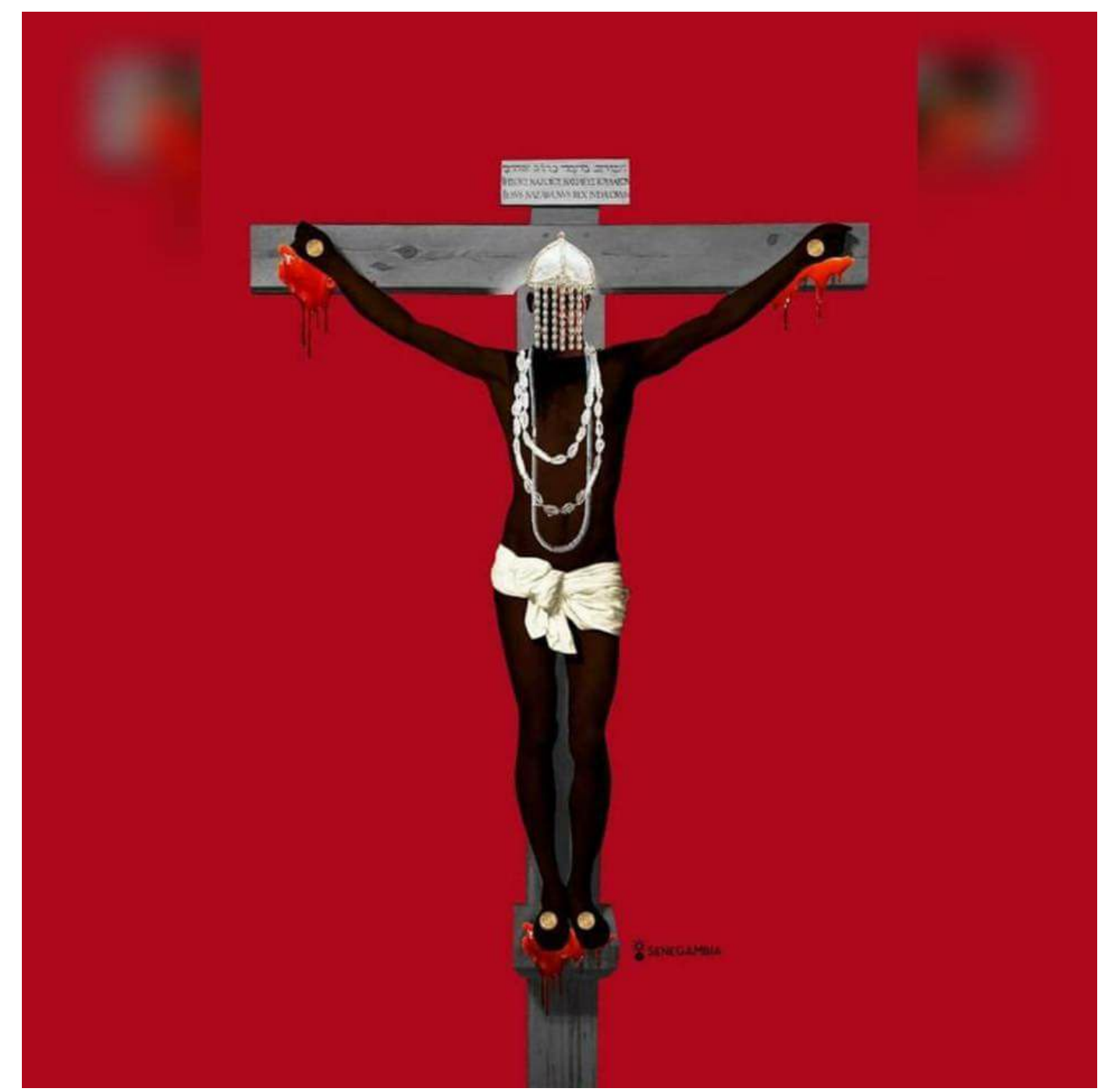

${ }^{72}<$ https://www.facebook.com/MacumbaOnlineBrasil/photos/a.435615476624038.1073741829.43 1713813680871/669863299865920/?type=3\&theater $>$ Acesso em 2 de nov. 2017 


\section{REFERÊNCIAS BIBLIOGRÁFICAS}

ALFANO, MARINATTO, ZUZANO e SOARES, Bruno, Luã, Pedro e Rafael. Um Rio de ódio: terreiro de candomblé é atacado com pedras, ovos

e legumes podres. Disponível em: <https://extra.globo.com/casos-depolicia/um-rio-de-odio-terreiro-de-candomble-atacado-com-pedras-ovoslegumes-podres-21645654.html> Acesso em 29 de out. 2017 ANSELMO, Eliane. "Da Mesa ao Terreiro”. Origem, Formação e Estrutura do Campo Religioso Afro-Brasileiro da Cidade de Areia Branca$R N$. Universidade Federal de Pernambuco - UFPE, 2005. [Pós-Graduação]. Disponível em:

$<$ http://repositorio.ufpe.br:8080/bitstream/handle/123456789/919/arquivo4 479 1.pdf? sequence=1\&isAllowed=y $>$ Acesso em 29 de out. 2017. Argumentação da Comissão de Preservação e Salvaguarda dos Terreiros Tombados referente ao Recurso Extraordinário $\mathrm{n}^{\mathrm{o}} 494.601$ - 7.210. Disponível em:

$<$ https://enugbarijo.wordpress.com/2017/05/11/argumentacao-dacomissao-de-preservacao-e-salvaguarda-dos-terreiros-tombados-referenteao-recurso-extraordinario-no-494-601-7210/> Acesso em 31 de out. 2017 BENTO, Maria Aparecida; SILVEIRA, Marly; NOGUEIRA, Simone. Identidade, Branquitude e Negritude. São Paulo: Casapsi Livraria e Editora Ltda, 2014.

Cartilha para Legalização de Casas Religiosas de Matriz Africana. Disponível em: $\quad<\underline{\text { http://www.jur.puc-rio.br/depto/wp- }}$ content/uploads/2013/08/Cartilha-para-Legaliza $\% \mathrm{C} 3 \% \mathrm{~A} 7 \% \mathrm{C} 3 \% \mathrm{~A} 30$-deCasas-Religiosas-de-Matriz-Africana.pdf> Acesso em 17 de out. 2017 Código Criminal do Império de 16 de dezembro de 1830. Disponível em <http://www.planalto.gov.br/ccivil 03/leis/lim/LIM-16-12-1830.htm> Acesso em 3 de jun. 2017. 
COSTA e GOMES, Valéria e Flavio. Religiões negras no Brasil da escravidão à pós-emancipação. São Paulo: Selo Negro, 2016.

Constituição Política do Império do Brasil. Disponível em $<$ http://www.planalto.gov.br/ccivil 03/constituicao/constituicao24.htm>

Acesso em 3 de jun. 2017.

Constituição da República Federativa do Brasil de 1988. Disponível em: $<$ http://www.planalto.gov.br/ccivil 03/constituicao/constituicao.htm>

Acesso em 27 de out. 2017

Declaração Universal dos Direitos Humanos. Disponível em: $<$ https://www.unicef.org/brazil/pt/resources_10133.htm $>$ Acesso em 28 de out. 2017

Decreto $\mathrm{n}^{\mathrm{o}}$ 43.252, de 22 de Julho de 2004. Disponível em: http://www.al.rs.gov.br/legiscomp/arquivo.asp?Rotulo=Lei $\% 20$ n $\%$ BA $\% 20$ $\underline{11915 \& \text { idNorma }=32 \& \text { tipo }=\text { pdf }}>$ Acesso em 31 de out. 2017

Decreto $\mathrm{n}^{\mathrm{o}}$ 6.040, de 7 de Fevereiro de 2007. Disponível em: <http://www.planalto.gov.br/ccivil_03/_ato2007-

2010/2007/decreto/d6040.htm> Acesso em 1 de nov. 2017

Dicionário do Aurélio Online - Dicionário Português. 2008-2017.

FERNADES, F. O Negro no Mundo dos Brancos. São Paulo: Editora Difusão Européia do Livro, 1972.

FLAUZINA, Ana Luiza Pinheiro. As Fronteiras Raciais do Genocídio. Revista de Direito da Universidade de Brasília, Brasília, v. 1, n. 1, jun. 2014.

HUMAN, Lia Vainer et al. Identidade, Branquitude e Negritude. São Paulo: Casapsi Livraria e Editora Ltda, 2014.

JESUS, Camila. Branquitude x Branquidade: uma análise conceitual do ser branco. Disponível em: $\quad<$ http://www3.ufrb.edu.br/ebecult/wpcontent/uploads/2012/05/Branquitude-x-branquidade-uma-ana\%C3\%83\%C3\%85lise-conceitual-do-ser-branco-.pdf> Acesso em 13 de out. 2017. 
JUNIOR, Ronaldo Laurentino de Sales. O TERREIRO E A CIDADE:

ancestralidade e territorialidade nas políticas ação afirmativa. Revista do Programa de Pós-Graduação em Sociologia da UFPE, v.2, n. 20, 2014.

Disponível em:

$<\underline{\text { http://www.revista.ufpe.br/revsocio/index.php/revista/article/view/391/32 }}$ 6> Acesso em 17 de out. 2017

KARASCH, Mary. A vida dos escravos no Rio de Janeiro (1808-1850). São Paulo: Companhia das Letras, 2000.

Lei de Diretrizes e Bases da Educação Nacional no 9.394/96. Disponível em: $<$ http://www.planalto.gov.br/ccivil 03/leis/L9394.htm $>$ Acesso em 30 de nov. 2017

Lei $\mathrm{n}^{\mathrm{o}} 11.915 / 03$, de 21 de Maio de 2003. Disponível em: $<$ http://www.al.rs.gov.br/legiscomp/arquivo.asp?Rotulo=Lei $\% 20 \mathrm{n} \% \mathrm{BA} \% 2$

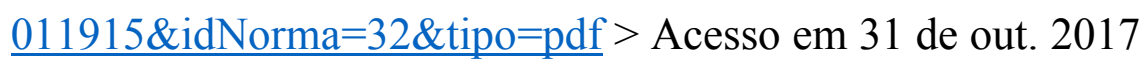

Lei $\mathrm{n}^{\mathrm{o}}$ 12.131, de 22 de Julho de 2004. Disponível em: $<\underline{\text { http://www.al.rs.gov.br/filerepository/repLegis/arquivos/12.131.pdf }>}$

Acesso em 31 de out. 2017

LEITE, Fabio Carvalho. Estado e Religião. A liberdade Religiosa no Brasil. Curitiba: Juruá Editora., 2014.

Levantamento elaborado por Malu Stanchi, Abyian de Oyá do Ilê Àse Omiojúàró e graduanda em Direito pelo PUC-Rio. Rio de Janeiro, set. 2017.

MATTOSO, Kátia M. de Queirós. Ser escravo no Brasil. Séculos XVI-XIX. Petrópolis, RJ: Vozes, 2016.

NASCIMENTO, Abdias do. O genocídio do negro brasileiro. Processo de um Racismo Mascarado. Rio de Janeiro: Editora Paz e Terra S/A, 1978.

Pesquisa Nacional, por amostra em domicílios. Síntese de indicadores 2014. IBGE. Disponível em:

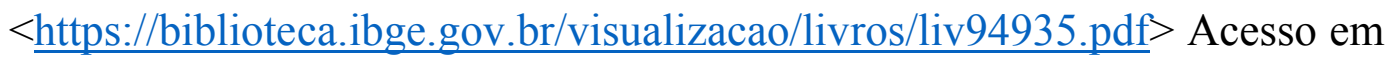
12 de out. 2017 
PIRES, Thula Rafaela. Criminologia crítica e pacto narcísico: por uma crítica criminológica apreensivel em pretuguês. Revista Brasileira de Ciência Criminais, São Paulo, n. 135, set. 2017.

POSSEBON, Roberta Mottin. A reação das religiões de matriz africana no Rio Grande do Sul: conflitos com neopentecostais e defensores dos animais. Pontifícia Universidade Católica do Rio Grande do Sul, 2007. [Pós-Graduação].

RIBEIRO, Josenilda Oliveira. Sincretismo religioso no Brasil: uma análise histórica das transformações no Catolicismo, Evangelismo, Candomblé e Espiritismo. Universidade Federal de Pernambuco, 2012. [Monografia] RODRIGUES, Yasmin. E os "brancos" do candomblé?. Disponível em: $<\underline{\text { https://olhardeumcipo.blogspot.com.br/2017/10/e-os-brancos-do- }}$ candomble.html?m=1 > Acesso em 29 de out. 2017

Síntese de Indicadores Sociais 2002. IBGE. Disponível em:

$<$ https://ww2.ibge.gov.br/home/presidencia/noticias/12062003indic2002.sh $\underline{\mathrm{tm}}>$ Acesso em 12 de out. 2017

SOARES, Afonso Maria Ligorio. Sincretismo afro-católico no Brasil: lições de um povo em exílio. Revista de Estudos da Religião, $\mathrm{n}^{0} 3$. Pontifícia Universidade Católica de São Paulo. 2002.

SOUZA, Neusa. Tornar-se negro ou As Vicissitudes da Identidade do Negro Brasileiro em Ascensão Social. Rio de Janeiro: Editora Graal Ltda., 1993.

VARGAS, João Costa. A Diáspora Negra como Genocídio: Brasil, Estados Unidos ou uma geografia supranacional da morte e suas alternativas. Revista da ABPN, Goiânia, v. 1, n. 2, jul. 2010

JORNAL O DIA. Denúncias de que traficantes teriam atacado terreiros são investigadas. Disponível em: $<$ http://odia.ig.com.br/rio-dejaneiro/2017-09-08/denuncias-de-que-traficantes-teriam-atacado-terreirossao-investigadas.html> Acesso em 29 de out. 2017 JORNAL O DIA. Em uma semana, seis ataques a casas de umbanda e candomblé em Nova Iguaçu. Disponível em: $<\underline{\text { http://odia.ig.com.br/rio-de- }}$ 
janeiro/2017-09-02/em-uma-semana-seis-ataques-a-casas-de-umbanda-ecandomble-em-nova-iguacu.html> Acesso em 29 de out. 2017

ALVES FILHO, Francisco. Religiosa obrigada a quebrar seu terreiro ao ser feita de refém por sete homens armados relata com exclusividade ao DIA o terror que passou. Disponível em: <https://www.geledes.org.br/me-

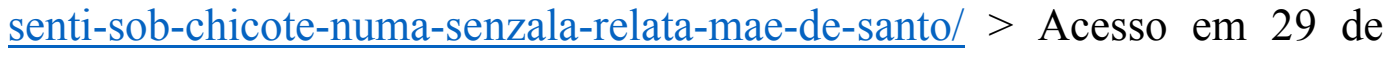
out. 2017

AREAIS, Karilayn. Idosa é agredida por intolerância religiosa em Nova Iguaçu. Disponível em: <http://odia.ig.com.br/rio-de-janeiro/2017-0820/idosa-e-agredida-por-intolerancia-religiosa-em-nova-iguacu.html>

Acesso em 29 de out. 2017

JORNAL O DIA. Casa do Mago é atacada pela terceira vez em menos de um mês. Disponível em: <http://odia.ig.com.br/rio-de-janeiro/2017-0816/casa-do-mago-e-atacada-pela-terceira-vez-em-menos-de-um-mes.html> Acesso em 29 de out. 2017

JUNIOR, Walmyr. Racismo religioso é o trato da intolerância no Brasil. Disponível em: <https://www.geledes.org.br/racismo-religioso-e-o-retratoda-intolerancia-no-brasil/> Acesso em 29 de out. 2017 